Revista Universo Contábil, ISSN 1809-3337
Blumenau, v. 16, n. 2, p. 87-109, abr./jun., 2020

\title{
STATE-OF-THE-ART: A SYSTEMATIC REVIEW OF THE LITERATURE ON FINANCIAL WELL-BEING
}
ESTADO DA ARTE: UMA REVISÃO SISTEMÁTICA DE LITERATURA SOBRE BEM-ESTAR FINANCEIRO

\section{ESTADO DEL ARTE: UNA REVISIÓN SISTEMÁTICA DE LA LITERATURA SOBRE EL BIENESTAR FINANCIERO}

Recebido em: 18-05-2020

Avaliado em: 29-07-2020

Reformulado em: 17-08-2020

Aceito para publicação em: 06-01-2021

Publicado em: 30-04-2021

Editor Responsável: Roberto Carlos Klann

\author{
Rafael Rudolfo Kreutz ${ }^{1}$ \\ Kelmara Mendes Vieira ${ }^{2}$ \\ Vanessa Rabelo Dutra ${ }^{3}$ \\ Wesley Vieira da Silva ${ }^{4}$
}

\begin{abstract}
This paper aims at presenting a systematic review of the literature based on the state of the art of research on financial well-being. We systematized a research protocol based on the works developed by Tranfield, Denyer, and Smart (2003), Kitchenham (2004), and Zupic and Čater (2015), to contribute to scientific knowledge about financial well-being, consistent with the methodological rigor required in RSL, which resulted in the composition of the research corpus. We search on the Scopus and Web of Science databases. The analysis includes all international publications between 1960 and 2018, comprising a total of 78 articles. Our results show that the financial well-being (demographic and socioeconomic variables, such as sex, ethnicity, age, income, education, and marital status), in addition to behavioral factors (attitude towards debt and financial literacy), may be indicative of theoretical gaps. We also evidenced that researchers have expended efforts on research involving the decision-making process in finance as a factor influenced by the satisfaction of people's lives.
\end{abstract}

Keywords: Financial Well-Being; Systematic Review; Behavioral Finance.

\footnotetext{
${ }^{1}$ Master in Public Organizations Management from the Federal University of Santa Maria; Administrator at the State University of Rio Grande do Sul; E-mail: rafael.kreutz@gmail.com

${ }^{2} \mathrm{Ph} . \mathrm{D}$. in Business Administration from the Federal University of Rio Grande do Sul (2006); Associate Professor at the Federal University of Santa Maria; kelmara.vieira@ufsm.br

${ }^{3}$ Ph.D. in Business Administration from the Federal University of Santa Maria (2020); Professor at the Federal University of Pampa; vanessadutra@ unipampa.edu.br

${ }^{4} \mathrm{Ph} . \mathrm{D}$. in Production Engineering from the Federal University of Santa Catarina; Professor of the Professional Master's Programs in Public Administration at the Federal University of Alagoas and Academic Master's in Administration at the Federal Rural University of the Semi-Arid, and CNPq Research Productivity Scholarship, Level 1D.; E-mail: wesley.silva@feac.ufal.br
} 


\section{RESUMO}

Este artigo tem como objetivo apresentar uma revisão sistemática da literatura baseada no estado da arte da pesquisa em bem-estar financeiro. Para contribuir com o conhecimento científico sobre o bemestar financeiro, foi sistematizado um protocolo de pesquisa com base nos trabalhos desenvolvidos por Tranfield, Denyer e Smart (2003), Kitchenham (2004) e Zupic e Čater (2015), consistente com o rigor metodológico exigido na RSL, que resultou na composição do corpus da pesquisa. A análise inclui todas as publicações internacionais entre 1960 e 2018. O corpus de pesquisa compreende um total de 78 artigos. Nossos resultados mostram o bem-estar financeiro associado a variáveis demográficas e socioeconômicas, como sexo, etnia, idade, renda, escolaridade e estado civil, além de fatores comportamentais, como atitude em relação ao endividamento e alfabetização financeira, os quais podem ser indicativos de lacunas teóricas. Isso também foi evidenciado pelo fato de os pesquisadores terem despendido esforços em pesquisas envolvendo o processo de tomada de decisão em finanças, como fator influenciado pela satisfação de vida das pessoas.

Palavras-chave: Bem-Estar Financeiro; Revisão Sistemática; Comportamento Financeiro.

\section{RESUMEN}

El propósito de este artículo es presentar una revisión sistemática de la literatura basada en el estado del arte de la investigación sobre bienestar financiero. Para contribuir al conocimiento científico sobre el bienestar financiero, se sistematizó un protocolo de investigación basado en el trabajo desarrollado por Tranfield, Denyer y Smart (2003), Kitchenham (2004) y Zupic y Čater (2015) de acuerdo con el rigor metodológico requerido. en RSL, que resultó en la composición del corpus de investigación. El análisis incluye todas las publicaciones internacionales entre 1960 y 2018. El corpus de investigación comprende un total de 78 artículos. Los resultados muestran que el bienestar financiero asociado con las variables demográficas y socioeconómicas, como el sexo, el origen étnico, la edad, los ingresos, la educación y el estado civil, además de los factores de comportamiento, como la actitud hacia la deuda y la educación financiera, pueden ser indicativos de vacíos teóricos. También se ha evidenciado por el hecho de que los investigadores se han dedicado a la investigación que involucra el proceso de toma de decisiones en las finanzas, como un factor influenciado por la satisfacción de la vida de las personas.

Palabras Clave: Bienestar Financiero; Revisión Sistemática; Finanzas Conductuales.

\section{INTRODUCTION}

Financial well-being is a topic of interest in several areas, including economics, financial planning and consulting, psychology, and consumer decision-making; however, there is no universally accepted definition and measure (Brüggen, Hogreve, Holmlund, Kabadayi, \& Löfgren, 2017, Sorgente \& Lanz, 2017). Some studies include financial well-being as a variable of interest. However, they do not make an effort to present a definition (O'Neill, Sorhaindo, Xiao, \& Garman, 2005; Prawitz, Garman, Sorhaindo, O’Neill, Kim, \& Drentea, 2006; Shim, Xiao, Barber, \& Lyons, 2009; Guo, Arnould, Gruen, \& Tang, 2013; Netemeyer, Warmath, Fernandes, \& Lynch Jr, 2018). The studies that present definitions of this construct use different approaches.

In the objective approach, we used income, financial information, financial indices (Greninger, 1996; Joo \& Grable, 2004; Kahneman \& Deaton, 2010), and liquidity (Aggarwal, 2014) as proxies for financial well-being. In the subjective approach, researchers examine people's perceptions and reactions to their financial conditions (Norvilitis, Szablicki, \& Wilson, 2003; O'Neill et al., 2005). Individuals in similar financial situations (assets or income) may realize their financial well-being differently, depending on their preferences. Moreover, it includes the people who have the same financial situation may assess their welfare more or less positively (Prawitz et al., 2006), 
personal characteristics (e.g., Joo \& Grable, 2004), and behavioral factors (Shim et al., 2009) that affect the subjective evaluation of financial well-being become relevant.

Despite the different conceptualizations and forms of measurement, there is evidence that financial well-being is associated with demographic, socioeconomic, and other behavioral factors such as gender, ethnicity, age, income, education, and marital status (Hira \& Mugenda, 1999). The attitude to indebtedness, financial behavior, and financial literacy (Adam, Frimpong, \& Boadu, 2017; Fazli Sabri, Cook, \& Gudmunson, 2012; Huston, 2010; Joo \& Grable, 2004; Shim et al., 2009; Taft, Hosein, \& Mehrizi, 2013, Ghazali, Alwi, Abd Aziz, \& Hazudin, 2020) are prominent behavioral factors.

The threats to financial well-being, which Shim et al. (2009) understand how the sentiment to the financial situation, is determined by the ease that contemporaneousness provides in the purchases, by the availability of credit and affordable means for loans and credit cards. The individual's financial well-being is also tied to a social and political-economic issue because the families most affected by financial concerns are low- and middle-income families (Lyons \& Yilmazer, 2005; Franko, 2020).

The lack of financial well-being is usually part of a vicious cycle involving financial problems, low income, and health. That is, poor health conditions directly affect the individual in their work capacity and generation of income. These difficulties lead to insufficient income for the satisfaction of basic requirements and medical care, which directly affect the family's ability to pay.

Thus the following research questions guided the development of this study. (i) What are the main approaches to financial well-being? (ii) Who are the principal authors that contribute to the development of research involving financial well-being? (iii) Which countries and journals are most responsible for the publications? (v) Is there a time evolution of the number of publications on the theme? and (vi) The Ghazali et al. (2020) agenda still valid?

Based on these questions, the paper aims at presenting a Systematic Review of Literature (SRL) on the financial well-being of individuals. For this, we used the research protocol developed by Tranfield et al. (2003) that resulted in the composition of the research corpus.

The development of this article highlights its relevance and originality, being the first to cover the gap in the literature. The objective of SRL is to identify a theoretical and practical overview of the methodologies used to solve specific problems and to analyze in which condition one uses a particular artifact to solve a problem. Also, SRL aims to eliminate the lack of reliability of studies made without scientific criteria or those based on convenience criteria (Brizola \& Fantin, 2016). Developing an SRL allows the identification, mapping, and analysis of relevant research on a literature theme. Thus, it helps to identify a research gap (Tranfield et al., 2003).

The main contributions consist of identifying the corpus of the research on financial wellbeing, providing evidence on the study results, mapping the characteristics approached internationally on the subject, and identifying trends for future research.

This study's structure has five sections. The first refers to the introduction; the second to the theoretical framework in which we analyzed the main concepts on financial well-being. The third section presents the study method. The fourth discusses the results; we present the concluding remarks and the suggestions for future studies in the fifth section.

\section{LITERATURE REVIEW}

\subsection{Financial well-being}

Financial well-being can be defined as the individual's classification to the perception of satisfaction regarding the adequacy of their income to their personal needs (Arber, Fenn, \& Meadows, 2014). Financial well-being is a state of being wherein a person can fully meet current and ongoing financial obligations, feel secure in their financial future, and make choices that allow enjoyment of life (Consumer Financial Protection Bureau, 2015). Similarly and Mahendru (2020) defines financial 
well-being as an individual's ability to quickly meet his/her current financial obligations and needs of the present and future and his/her temperament towards financial freedom today and tomorrow.

For Chan, Chau, and Chan (2012) and Malone, Stewart, Wilson and Korsching, (2010), to conceptualize and understand BEF, it is necessary to take into consideration the understanding and concern of individuals about the past, present, and future, that is, the financial experiences past, current and future expectations are important attributes. In this perspective, Delafrooz and Paim (2011) complement, stating that the construct BEF must contemplate financial satisfaction, the perception of financial resources, stability, and the objective value of goods. Also, the perception of $\mathrm{BEF}$ is different for individuals since they have different desires and conceptions about the future and perceptions about financial resources, stability, and the objective value of goods.

Thus, to identify people's financial satisfaction, it is necessary to analyze the context of life they live in and, consequently, the disposable income for families. Because of this, the more outstanding the debt concerning income, the lower the financial satisfaction tends to be. Therefore, an increase in income will not always translate into an increase in financial satisfaction since the level of debt may be high and, consequently, it will affect BEF (Vlaev \& Elliott, 2014).

To the ways of assessing the level of BEF, in the 90s, more objective aspects were still taken into account, related to family income, material items (food, clothing, housing, and transportation), financial resources available to attend emergencies; net worth (the difference between assets and all debts), the amount of debt, the level of savings and money for future needs (Sumarwan, 1990; Lown $\& \mathrm{Ju}, 1992)$. However, over the years, the uniquely objective situation about BEF has given rise to subjective aspects.

Among the international scales that use subjective indicators to measure BEF, there is the one developed by Norvilitis et al. (2003); another proposed by Prawitz et al. (2006), called Personal Financial Wellness Scale TM (PFW Scale TM); and more recently, in 2015, a new scale was released by the Consumer Financial Protection Bureau.

The scale developed by Norvilitis et al. (2003) was a measure of perception of Financial Wellbeing created for the study called "Factors Influencing Levels of Credit-Card Debt in College Students". It consists of eight items designed to measure feelings of confidence and financial security, scored on a 5-point scale ranging from 1 (strongly agree) to 5 (strongly disagree). The internal consistency was acceptable, and the scale consists of two main factors: the current financial concern and expectations for the future. The Personal Financial Wellness Scale ${ }^{\mathrm{TM}}$, on the other hand, consists of eight questions, which measure how people declare themselves about reactions and financial situations, from a 10-point Likert scale, ranging from negative feelings to positive feelings (Prawitz et al., 2006).

The most recent is the one developed by the Consumer Financial Protection Bureau (CFPB, 2015), designed to allow professionals and researchers to accurately and consistently quantify the $\mathrm{BEF}$ and therefore observe something that is not directly observable. Besides, being used as part of reports on the effectiveness of Education Programs and financial capacity. The developed measure's basis is insights from consumers and experts, captured through interviews and psychometric tests to ensure an accurate understanding of the questions.

\subsection{Financial Well-Being and Socioeconomic Variables}

The literature presents evidence of the association between financial well-being and socioeconomic and demographic variables such as gender, marital status, schooling, income, occupation, age, and religiosity (Chan, Omar, \& Yong, 2018; Gutter \& Copur, 2011; Penn, 2009; Sarofim, Minton, Hunting, Bartholomew, Zehra, Montford, Cabano, \& Paul, 2020).

From the gender perspective, men have higher levels of financial well-being than women (Gutter \& Copur, 2011). Women usually have greater evidence of economic adversity or financial stress, which affects their perception of financial well-being (Leach, Hayhoe, \& Turner, 1999). Regarding marital status, studies are incongruous in pointing out whether single or married 
individuals are more likely to be financially satisfied. Sumarwan (1990) and Diniz, Vieira, Potrich, and Campara (2014) concluded that married individuals are more likely to be satisfied with the resources and assets they have compared to single, divorced, or widowed individuals.

As for the income variable, Delafrooz and Paim (2011), Diniz et al. (2014), Fraga, Vieira, and Paraboni (2016), Gutter and Copur (2011), and Sumarwan (1990) observed that individuals with higher incomes are more likely to be satisfied with their financial situation. Lower-income consumers are more vulnerable to the loss of financial well-being due to their lower levels of financial reserves (Ponchio, Cordeiro, \& Gonçalves, 2019). Moreover, due to the ability of the rich to easily recover from economic downturns (Franko, 2020), in times of crisis, the rich lose less financial well-being than the poor.

When analyzing the occupation issue, Sumarwan (1990) points out that retirees have greater financial satisfaction than those employed or unemployed. Unemployment has a negative influence on financial well-being because it refers to income loss. Therefore, one can argue that it represents a difficulty to accumulate resources and refers to a scenario of financial difficulties due to anxiety related to the current financial situation (Plagnol, 2011; Sumarwan, 1990). Also, Diniz, Vieira, Potrich, and Campara (2015) emphasize that individuals with public occupations tend to have a greater perception of financial well-being.

Analyzing the variable age, the older individuals present greater financial well-being than the younger ones (Kunkel, Vieira, \& Potrich, 2015; O’Neill et al., 2005; Plagnol, 2011; Collins \& Urban, 2020). Two reasons can explain this relationship. The first because the greater, the younger the material aspirations. Therefore, it insinuates the reduction of the need to spend beyond the capacity to pay. The second reason is that the advancement of the age usually accumulates financial assets, providing greater financial tranquility (Plagnol, 2011).

\section{METHOD}

The systematization of a research protocol has guided the systematic review, which provides legitimacy and provides a structured knowledge base for decision-makers (Tranfield et al., 2003). To ensure a Systematic Literature Review, we previously defined a series of criteria, which comprise the research protocol. We present the flowchart with the steps of the SRL protocol used in this research in Figure 1.

We developed the search process during July 2018. The keywords "financial and well-being" or "wellbeing" used for searches should be in the articles' title, abstract, or keywords. The period of analysis was from 1960 to 2018. We found 5,509 articles in the Scopus and 3,164 in the Web of Science database.

As our purpose was to extract the articles, which were effectively linked to international periodicals and dealing with the theme, we create specific filters. Regarding the documents, we decided to use only "Article" in "Portuguese", "English" and "Spanish". Also, a "People" filter was applied to restrict the search for people's well-being. After applying these parameters, the bases included 1,603 articles in Scopus and 519 articles in the Web of Science.

Subsequently, the Scimago Journal Ranking was used to filter through the thematic areas "Economics, Econometrics and Finance, Econometrics and Finance", "Business, Management and Accounting", and Psychology. Finally, the last filter used was selecting journals classified in the first and second quarters of citation (Q1 and Q2) of the SJR. After applying these parameters, we found 249 articles on Financial Well-Being. After this process, the duplicate articles were excluded from the databases, remaining 199 articles. Finally, through reading the abstracts, we verified the articles' adherence to the topic to be investigated. At the end of the process, there were 78 articles. 
Figure 1

Process Model for Systematic Literature Review

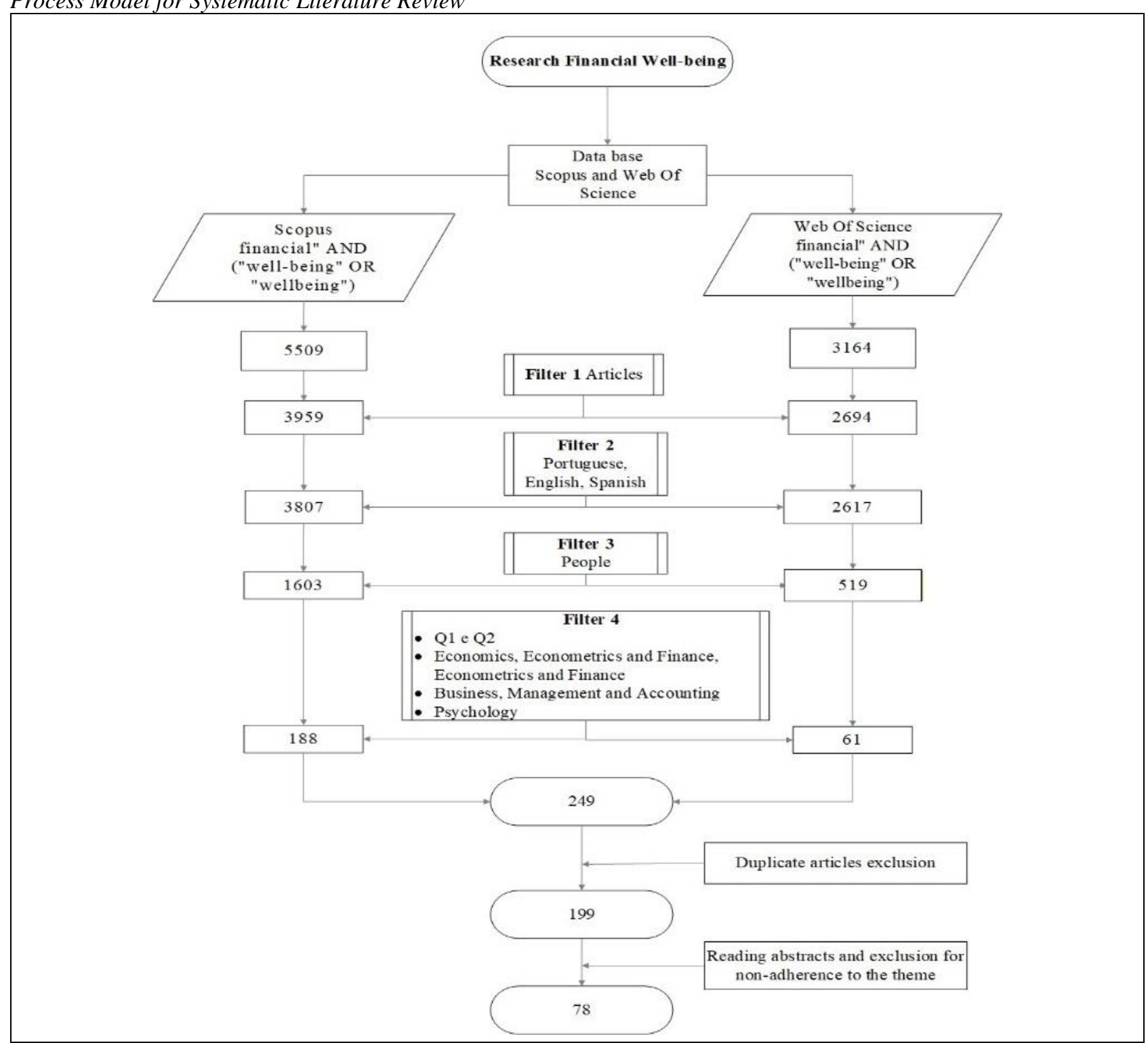

Source: Developed by the authors (2018).

\section{ANALYSIS AND DISCUSSION OF RESULTS}

In this section, we present the results of the study. First, we describe the research corpus and the seminal articles on financial well-being. In the sequence, we present the indicators and the relationship networks between institutions and authors. We also conducted a Lexical analysis. Finally, we conduct a content analysis of the most recent articles on financial well-being.

\subsection{Descriptive Analysis of the Research Corpus}

The corpus of the research comprises 78 articles, which cover 51 journals and 215 authors and co-authors registered in the Web of Science and Scopus databases. Figure 2 reports the results of the publications distributed over the years, showing the quantity published annually. We observed that even though the research has a period of coverage between 1960 and 2018, publication records began in 1987. Furthermore, the results reveal that between 1987 and 2002, there was not much variability in the number of published articles. Between 2005 and 2016, there is a tendency to increase the number of articles, from 1 register (1\%) in 2005 to 12 (15\%) in 2016. 
There are 78 articles published, 58 in the period from 2010 to 2018 , representing $74.35 \%$ of the research corpus. In this period, the year 2016 is the one with the highest number of published articles, 12 articles (15\%). We highlight the work developed by Boyce, Wood, and Ferguson (2016) entitled Individual Differences in Loss Aversion: Conscientiousness Predicts How Life Satisfaction Responds to Losses Versus Gains in Income and published in Personality and Social Psychology Bulletin, which obtained a total of 89 citations received. Between 2017 and 2018, there was a tendency to decrease the number of publications, going from 12 in 2016 to 8 , a decrease of $33.33 \%$ in 2018.

With regarding the geographical distribution of published articles, from the institutional link, 215 authors and co-authors distributed in 24 countries were documented as evidence, as shown in Figure 2. We found that the United States is responsible for 48 articles, or $61.5 \%$ of the corpus. In second place is the United Kingdom, with a total of 10 articles (12.82\%).

Canada, Australia, New Zealand, China and Spain are responsible for the publication of 7 (9\%), 6 (7.7\%), $5(6.4 \%), 4(5.1 \%)$ and 3 articles (3.8\%), respectively. Regarding Switzerland, Italy, Germany, Finland, and Brazil publishedtwo2 articles each. The other countries, Turkey, South Korea, South Africa, Siberia, Portugal, Poland, Malaysia, Israel, India, Iceland, Denmark, and Belgium, submitted only one article.

To identify and describe the main lines of financial well-being research, we incorporate the textual corpus into the search tool developed by the National University of Colombia, called Tree of Science (ToS). It consists of a network analysis of citations from graph theory. With this feature, researchers create a text file with the selected references, using graph theory concepts through the analysis of the citation networks. The tree classifies the references found in three levels: root, which gathers the seminal articles; trunk, which aggregates structuring articles; and leaves, which indicate the recent articles.

Figure 2

Distribution of textual corpus' authors by country

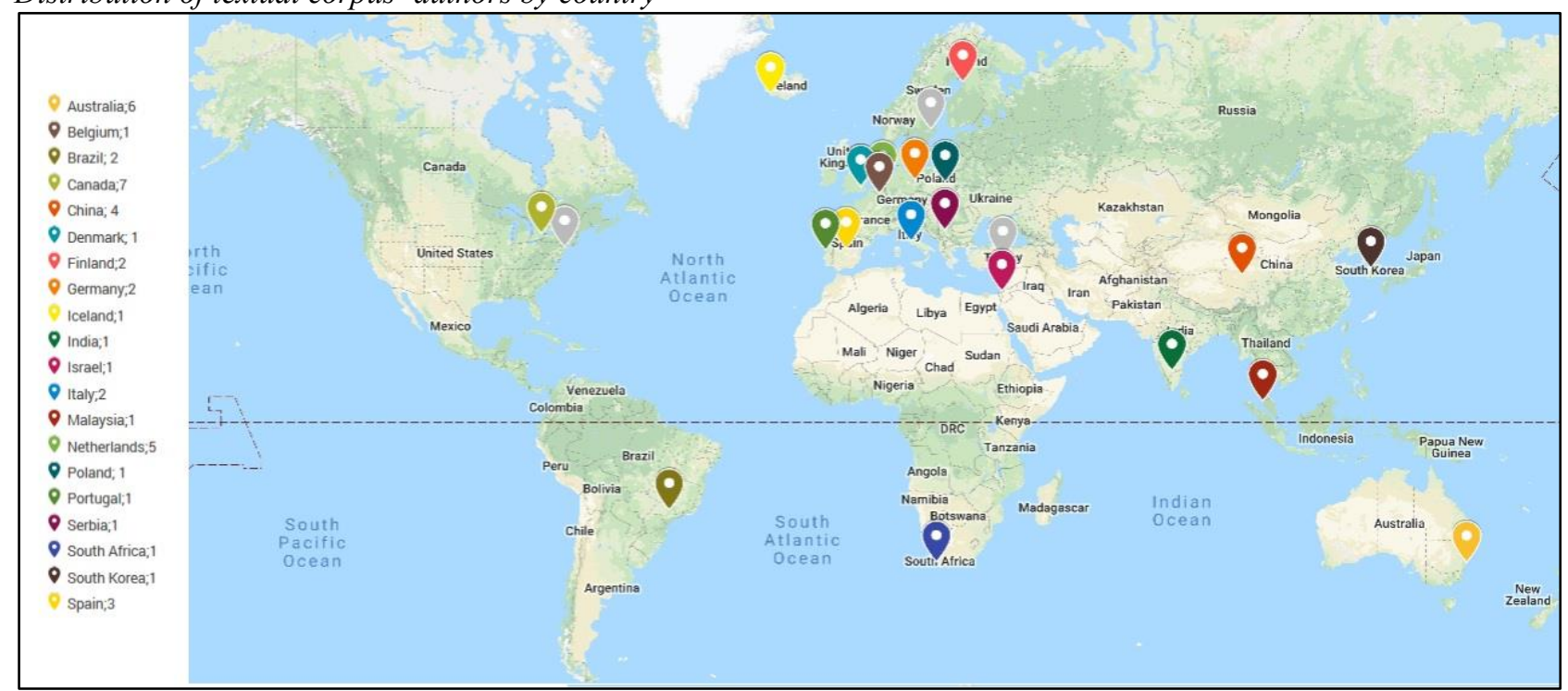

Source: Organized by the authors according to RSL with maps (2018).

The tree consists of 78 articles distributed as follows: 10 articles classified as root and colored in orange. The root region covers the literature that provides an initial basis. In the trunk, there are ten articles colored in brown. There are articles with citations in this region and are the most cited within the study area and represent the structural publications. Finally, in the leaves, colored in green, there are the most recent articles on the theme. 
Figure 3

Tree of Science to financial well-being

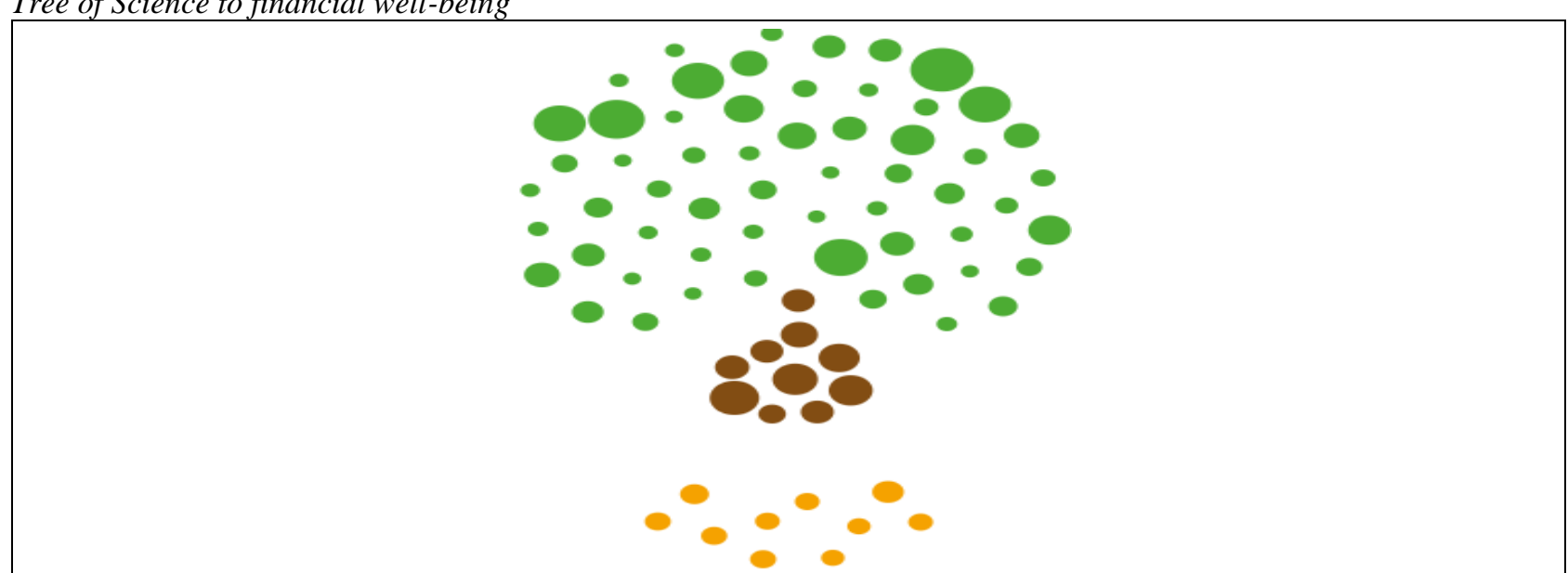

Source: Organized by the authors.

From Table 1, it is possible to identify the ten articles that stand as those that support the theories of financial well-being. We should note that these articles do not necessarily appear in the database but rather in the references of the records. The articles presented a total of 96,685 citations.

Table 1

Seminal authors of research theory

\begin{tabular}{|c|c|c|c|c|}
\hline Authors & Year & Title & Journal & TC \\
\hline $\begin{array}{l}\text { Aiken Leona S; } \\
\text { West Stephen G; } \\
\text { Reno Raymond R }\end{array}$ & 1991 & $\begin{array}{l}\text { Multiple regression: Testing and interpreting } \\
\text { interactions }\end{array}$ & Sage Publications & 40056 \\
\hline $\begin{array}{l}\text { Diener Ed.; Biswas- } \\
\text { Diener Robert }\end{array}$ & 1985 & The Satisfaction With Life Scale & $\begin{array}{l}\text { Social Indicators } \\
\text { Research }\end{array}$ & 21695 \\
\hline Diener Ed. & 1984 & Subjective well-being & $\begin{array}{l}\text { Psychological } \\
\text { Bulletin }\end{array}$ & 12568 \\
\hline $\begin{array}{l}\text { Diener Ed.; Suh } \\
\text { EM, Lucas RE \& } \\
\text { Smith HL }\end{array}$ & 1999 & Subjective well-being: Three decades of progress & $\begin{array}{l}\text { Psychological } \\
\text { Bulletin }\end{array}$ & 11839 \\
\hline $\begin{array}{l}\text { Marsha L Richins } \\
\text { Scott Dawson }\end{array}$ & 1992 & $\begin{array}{l}\text { A Consumer Values Orientation for Materialism and Its } \\
\text { Measurement: Scale Development and Validation }\end{array}$ & $\begin{array}{l}\text { Journal of } \\
\text { Consumer } \\
\text { Research }\end{array}$ & 3236 \\
\hline $\begin{array}{l}\text { Diener Ed.; Biswas- } \\
\text { Diener Robert }\end{array}$ & 2002 & Will Money Increase Subjective Well-Being? & $\begin{array}{l}\text { Journal of } \\
\text { Personality } \\
\text { Assessment }\end{array}$ & 3074 \\
\hline $\begin{array}{l}\text { Dolan P Peasgood T } \\
\text { \& White } \mathrm{M}\end{array}$ & 2008 & $\begin{array}{l}\text { Do we really know what makes us happy? A review of } \\
\text { the economic literature on the factors associated with } \\
\text { subjective well-being }\end{array}$ & $\begin{array}{l}\text { Journal of } \\
\text { Economic } \\
\text { Psychology }\end{array}$ & 2151 \\
\hline $\begin{array}{l}\text { Lusardi Annamaria, } \\
\text { Olivia S Mitchel }\end{array}$ & 2007 & $\begin{array}{l}\text { Baby Boomer retirement security: The roles of planning, } \\
\text { financial literacy, and housing wealth }\end{array}$ & $\begin{array}{l}\text { Journal of } \\
\text { Monetary } \\
\text { Economics }\end{array}$ & 1727 \\
\hline $\begin{array}{l}\text { Diener Ed; Wolsic } \\
\text { B \& Fujita F }\end{array}$ & 1995 & Physical attractiveness and subjective well-being & $\begin{array}{l}\text { Journal of } \\
\text { Personality and } \\
\text { Social } \\
\text { Psychology, }\end{array}$ & 310 \\
\hline Layard Richard & 2005 & Happiness: Lessons from a New Science & Pen-guin Group & 29 \\
\hline
\end{tabular}

Source: Organized by the authors (2018)

Note: TC - Total Citations 
The articles presented a total of 96,685 citations. The most recent seminal articles date from 2007 and 2008. It is noteworthy that the author Diene has $5(50 \%)$ seminal works in the corpus and $51.18 \%$ of the total citations. That is, he can be considered one of the principal authors in the financial well-being theme. In his most cited article entitled "The Satisfaction with Life Scale", the author reports the development and validation of a scale to measure overall satisfaction with life, called the Life Satisfaction Scale (SWLS).

In Table 2, it is possible to identify the papers that are in the trunk of the tree, which aggregates structuring articles.

Table 2

Main authors and papers that are in the leaves of the tree of science

\begin{tabular}{|c|c|c|c|}
\hline Authors & Yers & Title & Journal \\
\hline $\begin{array}{l}\text { McCabe, S., Joldersma, } \\
\text { T., \& Li, C. }\end{array}$ & 2010 & $\begin{array}{l}\text { Understanding the benefits of social tourism: } \\
\text { Linking participation to subjective well-being and } \\
\text { quality of life. }\end{array}$ & $\begin{array}{l}\text { International Journal } \\
\text { of Tourism Research }\end{array}$ \\
\hline $\begin{array}{l}\text { Lekes, N., Gingras, I., } \\
\text { Philippe, F. L., Koestner, } \\
\text { R., \& Fang, J. }\end{array}$ & 2009 & $\begin{array}{l}\text { Parental Autonomy-Support, Intrinsic Life Goals, } \\
\text { and Well-Being Among Adolescents in China and } \\
\text { North America. }\end{array}$ & $\begin{array}{l}\text { Journal of Youth and } \\
\text { Adolescence }\end{array}$ \\
\hline Stanca, L. & 2012 & $\begin{array}{l}\text { Suffer the little children: Measuring the effects of } \\
\text { parenthood on well-being worldwide. }\end{array}$ & $\begin{array}{l}\text { Journal of Economic } \\
\text { Behavior \& } \\
\text { Organization }\end{array}$ \\
\hline Mookherjee, H. N. & 1997 & $\begin{array}{l}\text { Marital Status, Gender, and Perception of Weil- } \\
\text { Being. }\end{array}$ & $\begin{array}{l}\text { The Journal of Social } \\
\text { Psychology }\end{array}$ \\
\hline $\begin{array}{l}\text { Creed, P. A., \& Watson, } \\
\text { T. }\end{array}$ & 2003 & $\begin{array}{l}\text { Age, Gender, Psychological Wellbeing and the } \\
\text { Impact of Losing the Latent and Manifest Benefits } \\
\text { of Employment in Unemployed People. }\end{array}$ & $\begin{array}{l}\text { Australian Journal of } \\
\text { Psychology }\end{array}$ \\
\hline Dynan, K. E. & 2009 & $\begin{array}{l}\text { Changing household financial opportunities and } \\
\text { economic security. }\end{array}$ & $\begin{array}{l}\text { Journal of Economic } \\
\text { Perspectives }\end{array}$ \\
\hline $\begin{array}{l}\text { Creed, P. A., \& Bartrum, } \\
\text { D. A. }\end{array}$ & 2008 & $\begin{array}{l}\text { Personal Control as a Mediator and Moderator } \\
\text { Between Life Strains and Psychological Well-Being } \\
\text { in the Unemployed. }\end{array}$ & $\begin{array}{l}\text { Journal of Applied } \\
\text { Social Psychology }\end{array}$ \\
\hline $\begin{array}{l}\text { Rahtz, D. R., Sirgy, M. J., } \\
\text { \& Meadow, H. L. }\end{array}$ & 1989 & $\begin{array}{l}\text { The elderly audience: Correlates of television } \\
\text { orientation. }\end{array}$ & Journal of Advertising \\
\hline $\begin{array}{l}\text { Chancellor, J., \& } \\
\text { Lyubomirsky, S. }\end{array}$ & 2011 & $\begin{array}{l}\text { Happiness and thrift: When (spending) less is } \\
\text { (hedonically) more. }\end{array}$ & $\begin{array}{l}\text { Journal of Consumer } \\
\text { Psychology }\end{array}$ \\
\hline $\begin{array}{l}\text { Rick, S. I., Small, D. A., } \\
\text { \& Finkel, E. J. }\end{array}$ & 2011 & $\begin{array}{l}\text { Fatal (Fiscal) Attraction: Spendthrifts and } \\
\text { Tightwads in Marriage. }\end{array}$ & $\begin{array}{l}\text { Journal of Marketing } \\
\text { Research }\end{array}$ \\
\hline
\end{tabular}

Source: Organized by the authors (2018).

Note: TC - Total Citations.

\subsection{Analysis of Cooperation Networks Between Institutions}

We carried out the analysis of cooperation networks among institutions to identify which institutions were the most important in researching cooperation on Financial Well-Being. Moreover, Figure 4 was elaborated due to the VOSviewer software's help and considered criteria the minimum number of 1 document and one citation per institution.

There were 151 organizations belonging to the research corpus, of which 125 met these criteria. Only 22 organizations showed connections with others; that is to say, we only used those that showed cooperative research development (Figure 4). As a result, it is possible to identify that these 22 organizations from 3 cooperation clusters have 86 links or relational links. 
Figure 4.

Distribution of textual corpus cooperation network by university

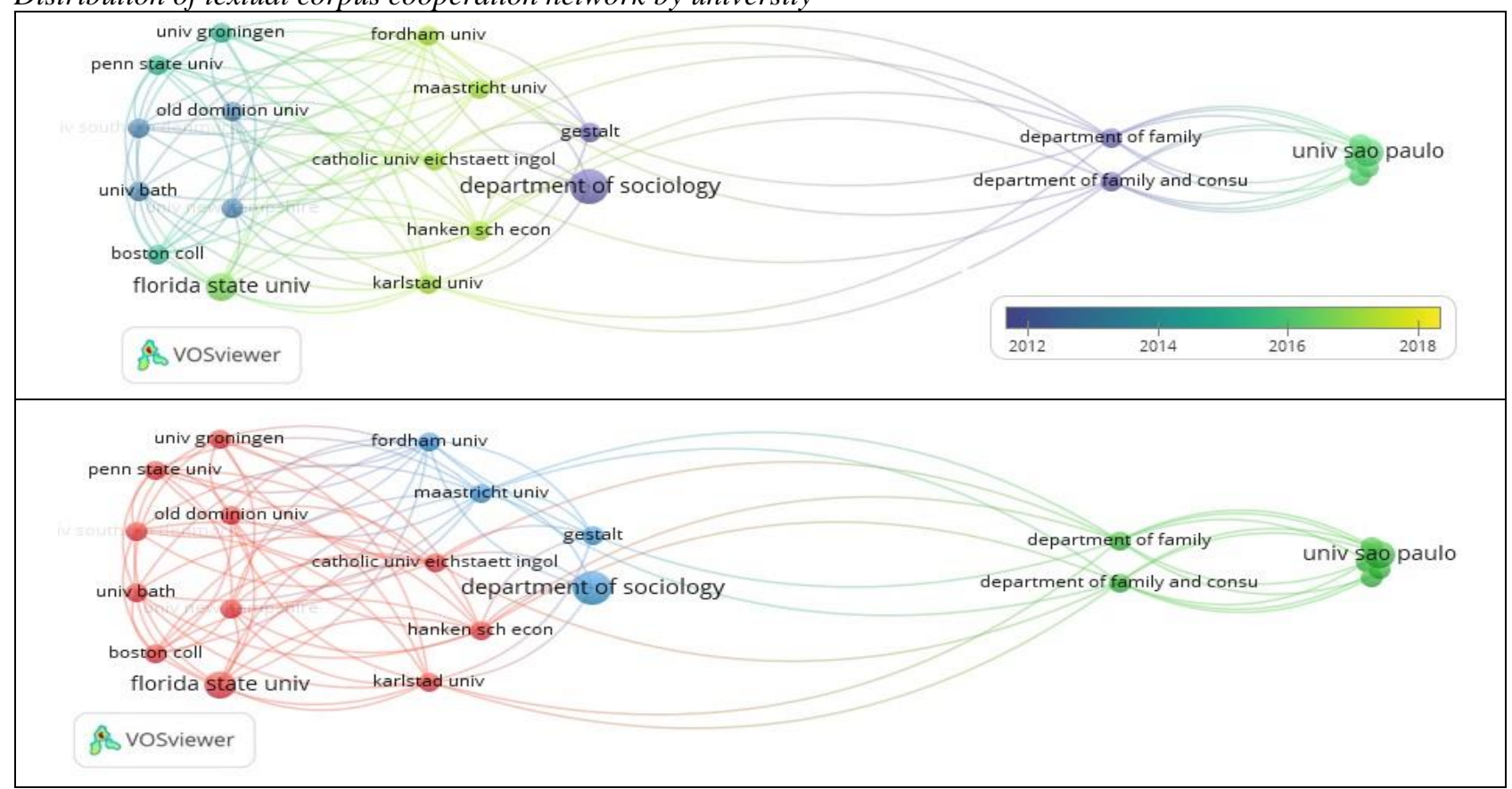

Source: Prepared by the authors according to RSL (2018) with VOSviewer.

Cluster 1, colored in red, comprises 11 institutions emphasizing Florida State University in the United States, which presented the largest cooperation network with nine relational ties and two published articles. Cluster 2, colored in green, comprises seven institutions emphasizing the University of São Paulo do Brazil with two relational ties and two articles. Cluster 3, colored in blue, composed of 4 institutions, was highlighted by the United States Department of Sociology with five relational ties and three articles. Thus, we can consider that these three institutions are the ones that stood out the most in terms of researching cooperation. Moreover, it appears that Florida State University and the University of São Paulo are the institutions that present the most recent articles on the theme dating from 2016. The Department of Sociology presents older articles (1999). Most institutions belonging to the United States demonstrate that they are more likely to research in conjunction with other institutions.

\subsection{Analysis of Authors, Co-Authors, and Productivity of Journals}

The analysis of co-citation of authors was carried out based on the research protocol proposed by Tranfield et al. (2003), Kitchenham (2004), and Biolchini, Mian, Natali, Conte, and Travassos (2007) us to verify the frequency of citation of two authors simultaneously by another author of the literature (Small, 1973). Wallin (2005) points out that the greater the number of researchers citing the same two publications, the greater the probability this occurrence is not a mere chance, i.e., there is a relationship between the subjects within a search.

The authors' coercing network, extracted from the 4,734 authors, is shown in Figure 5. The type of analysis chosen was "co-citation", with the analysis unit "cited authors" and the counting method "full counting". Also, we defined ten citations for each author as a criterion. We applied these parameters for better visualization of the network.

As a result, it is possible to verify 30 authors grouped in 4 clusters with 40 nodes, representing 233 relational links between them simultaneously. The node's thickness is proportional to the number of citations of each author, and the lines establish the relation of co-citation between the authors. 
Figure 5

Network of co-citation of authors of the research corpus

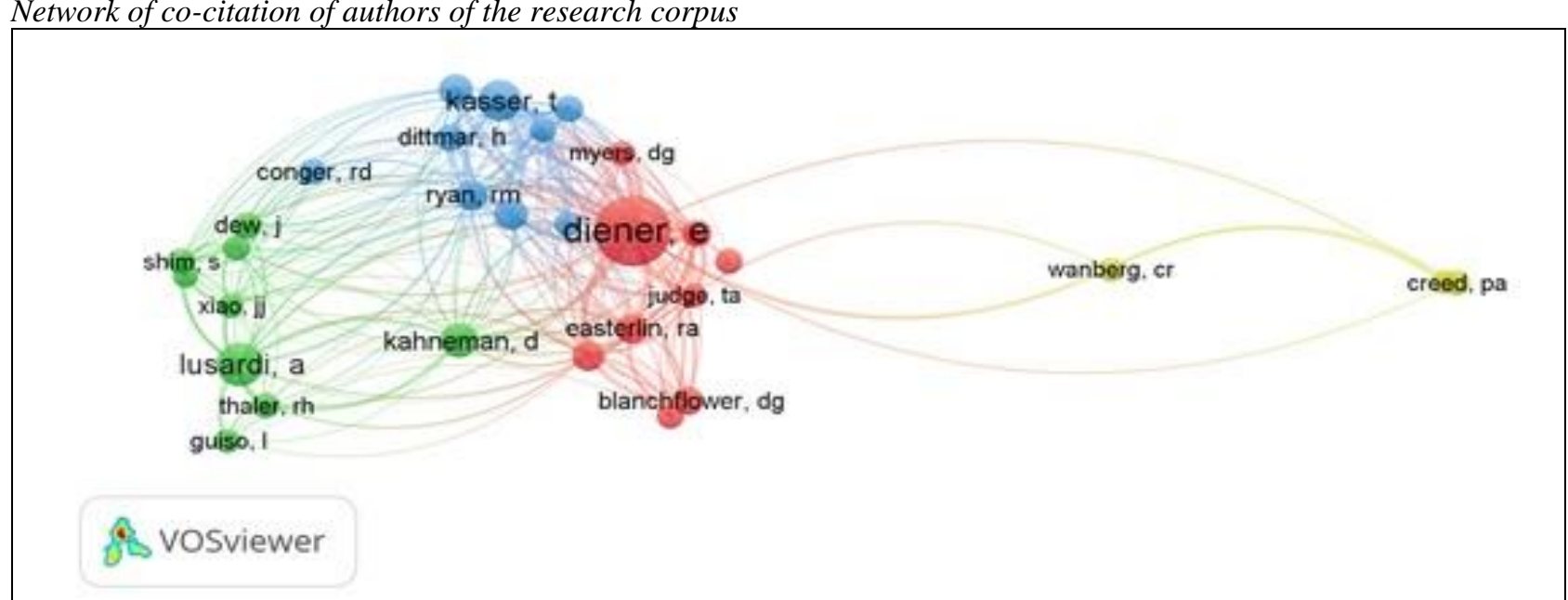

Source: Prepared by the authors according to RSL (2018) with VOSviewer.

According to Figure 5, it is possible to verify the formulation of 4 clusters. The node's thickness is proportional to the amount of citation of each author, and the lines establish the relationship of co-citation between the authors.

In cluster 1, colored red, composed of 9 authors, we highlight the author Diener (1985), who has 87 citations and 28 relational links. Cluster 2, colored green, comprises nine authors, and the author who stands out is Lusardi and Mitchell (2007), with 34 citations and 15 relational links. In cluster 3, colored blue, also composed by nine authors, the authors Kasser and Ryan (1993) have 29 citations and 19 relational nods. Finally, cluster 4 (yellow) comprises three authors, which Creed and Bartrum (2008) stand out with 11 citations and three relational links.

Evaluating the productivity of researchers and journals through citation indicators has gained increasing importance because it offers a set of systematized information that aims to describe the dynamics and density of contributions around a theme or specialty.

Along this line, it is important to evaluate the productivity of the journals in the investigated field based on the selected textual corpus. We used the "Bradford law" as a basis, which according to Guedes (2012, p. 81), "allows estimating the degree of relevance of journals in an area of knowledge, that journals that produce a greater number of articles on the subject form a nucleus of journals, supposedly of higher quality or relevance to that area".

Bradford's Law demonstrates the existence of a nucleus of journals that can be considered as the most productive in a given area since they present a greater number of articles on a given topic. Thus, the law sorted journals according to productivity zones. The Journal of Family and Economic Issues published nine articles on the topic of financial well-being.

For the journal selection, we used the Scimago Journal Ranking (SJR) classification. We highlight that $48.72 \%$ of published articles in the textual corpus were in journals located in the first quartile of citations in the Scimago Journal Ranking (SJR) (2018) and 51.28\% in the second quartile, which represents a high reputation of the analyzed journals.

\subsection{Bibliographic Coupling Analysis}

Bibliographic coupling analysis (BCA) helps to identify epistemologies, theories, and methodological traits that influence a scientific domain, mainly to highlight its epistemic community (Araújo \& Guimarães, 2017). The BCA method is based on the hypothesis of measuring the similarity between pairs of documents, referring to the same source, and used in the shared quotations (Kessler, 
1965). As shown in Figure 6, it is possible to view the network of linked documents, distributed in 4 clusters, in which each node represents one of the articles that make up the research corpus.

Figure 6

Network of documents coupled with the number of citations

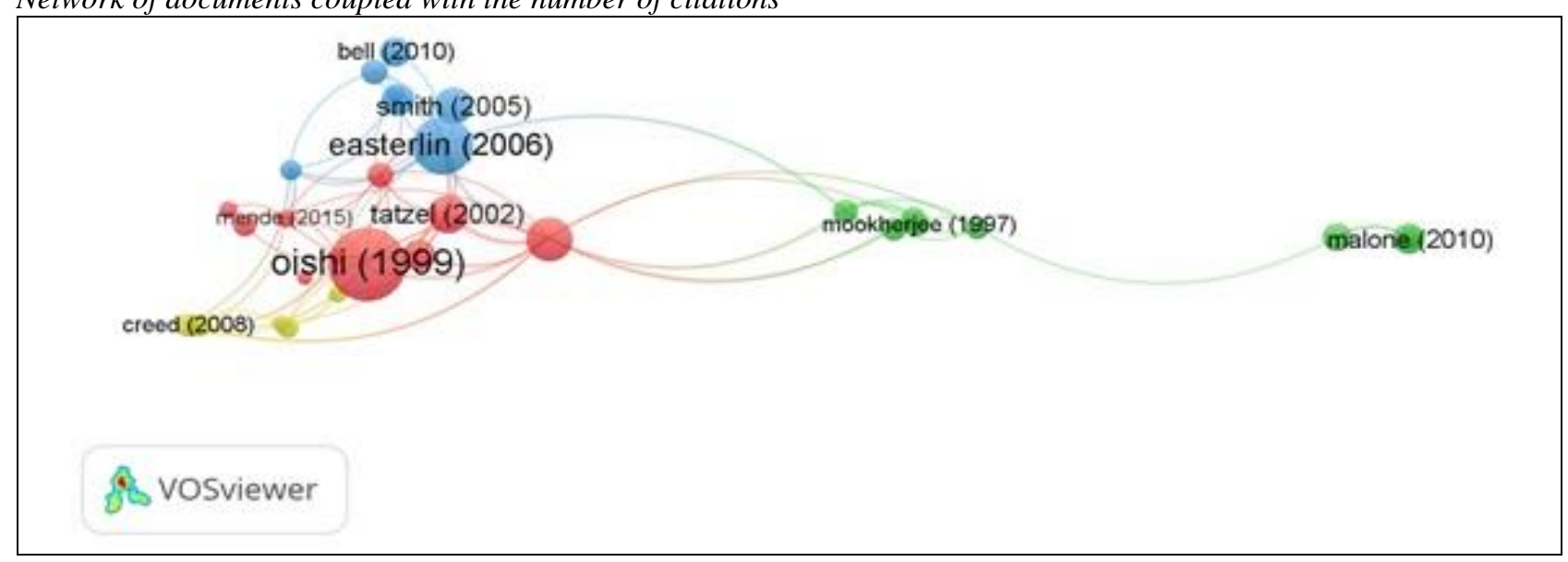

Source: Prepared by the authors according to RSL (2018) with VOSviewer

We performed a document coupling analysis using the VOSviewer software and define some parameters to develop the network. We applied "Bibliographic coupling" to the type of analysis; "Documents" for the unit of analysis and "full counting" for the counting method. We assign the same weight to each link between documents. The data analyzed in the network comprised 34 articles, with at least ten citations, extracted from the textual corpus (78 articles). This configuration provided a better view of the network, resulting in 29 attached documents.

Cluster 1, colored red, comprises ten documents coupled. The work developed by Oishi, Diener, Lucas, and Suh (2009), entitled "Cross-cultural variations in predictors of life satisfaction: Perspectives from needs and values", presented a total of 270 citations, representing $44.40 \%$ of citations received by all documents in cluster 1 and $20.05 \%$ to all clusters.

Cluster 2, colored green, is composed of 8 linked documents. The work of Malone et al. (2010), entitled "Perceptions of financial well-being among American women in diverse families", stands out for representing $21.49 \%$ of the group's quotations. Cluster 3, colored blue, has seven documents. In terms of the number of citations, the highlight is the work of Easterlin (2006), entitled "Life cycle happiness and its sources - Intersections of psychology, economics, and demography, which had a total of 163 citations, representing $40.54 \%$ of the citations of the cluster. Cluster 4, colored yellow, contemplates five documents. The article by Creed and Bartrum (2008), entitled "Personal control as a mediator and moderator between life strains and psychological well-being in the unemployed", was evidenced with $25.92 \%$ of the total citations of this group.

Bibliographic coupling is considered as an adequate analysis to identify evolutionary, besides the current patterns of a specific research domain (Zupic \& Čater, 2015). In this sense, this analysis makes it possible to develop the research lines. It allows identifying research nuclei, researchers, and the works considered most important in a given scientific domain (Carvalho, 1975). Furthermore, Li, Porter, and Wang (2017) state that, unlike the authors' traditional co-citation analysis, coupling analysis is a method of grouping co-citations from different works to correlate the different research topics.

\subsection{Word Cloud Analysis and Similitude}

The word cloud corresponds to the organization and grouping the frequency of words from the graphical representation of their occurrences, allowing identifying the lexical content and the central themes of the textual corpus of the research. In this work, we formulated the cloud from the 
words contained in the abstract of the 78 articles analyzed. The word cloud was elaborated based on the simple and estimated lexical analysis from IRAMUTEQ software.

The word cloud technique consists of interesting lexical analysis, in which it intends to present a graphical representation of the frequency or the occurrence of words (Camargo \& Justo, 2013). The analysis of words aims to evaluate the textual corpus through lexical analysis. DePaolo and Wilkinson (2014) emphasize that the size of each one indicates its frequency of occurrence in the word cloud. Words in Figure 7 are presented randomly according to frequency. The higher the occurrence, the larger the word, which demonstrates its prominence in the corpus.

The analysis identified 628 words with frequency and/or a minimum occurrence of 3 times in a total of 13890 occurrences in the research corpus. However, to develop the word cloud, the minimum frequency parameter of 10 was adopted. This configuration provided a better view of the cloud, resulting in 180 words, as shown in Figure 7.

Figure 7

Word Cloud

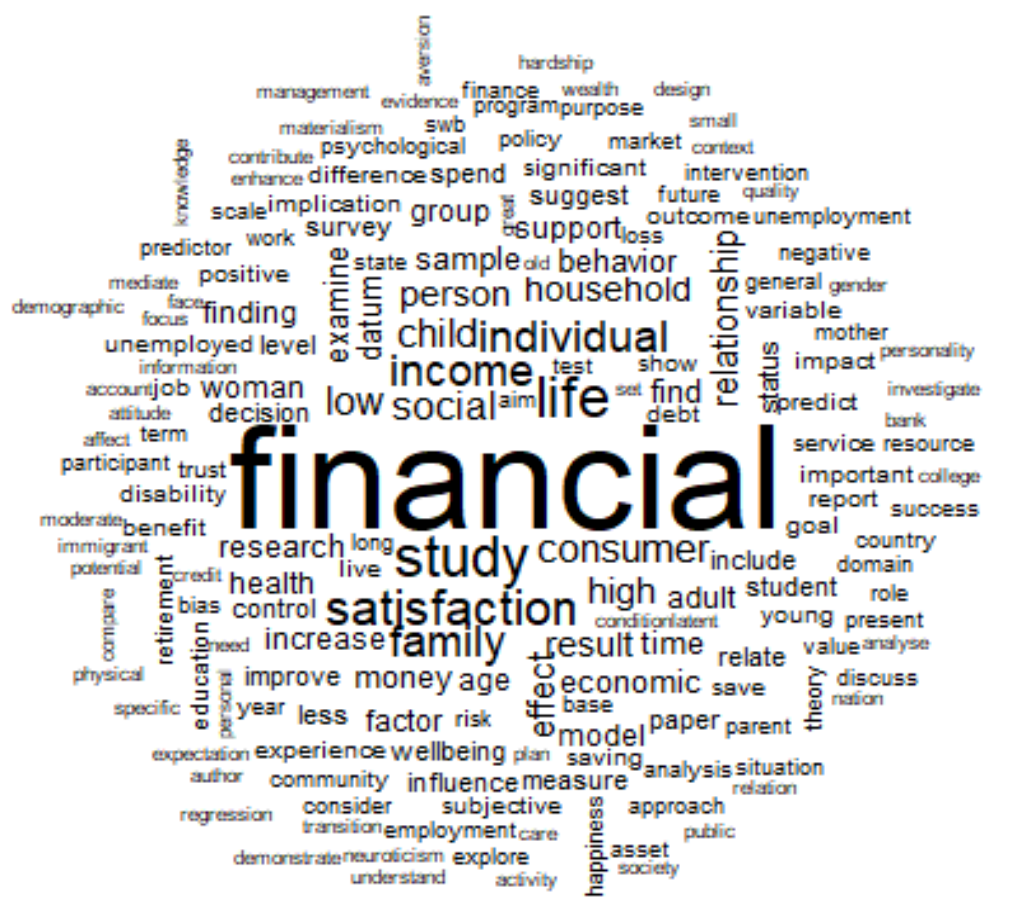

Source: Prepared by the authors according to RSL (2018) with Iramuteq.

Among the five words with the highest frequency of occurrence are the words "Finance", 267 occurrences, followed by the word "Study", 86 occurrences, "Live", 83 occurrences, 70 records for the word "Satisfaction", and 60 occurrences for "Income". The words "Family" and "Individual" also presented relevant occurrences of 59 and 58, respectively. The result indicates that greater representativeness in the academic environment has directed its focus to subjects that aim to identify the financial satisfaction in people's lives from the analysis of the familiar income.

The similarity analysis is based on the co-occurrence of words, and its result indicates the connection between them, aiding in the identification of representation based on graph theory. From this analysis, it is possible to identify cohesion between the words and highlight a connection between them. Moreover, to elaborate on the network presented in Figure 8, the criterion of the minimum frequency of twenty occurrences was used for each word, resulting in 65 words. 
Figure 8

Results of similitude analysis

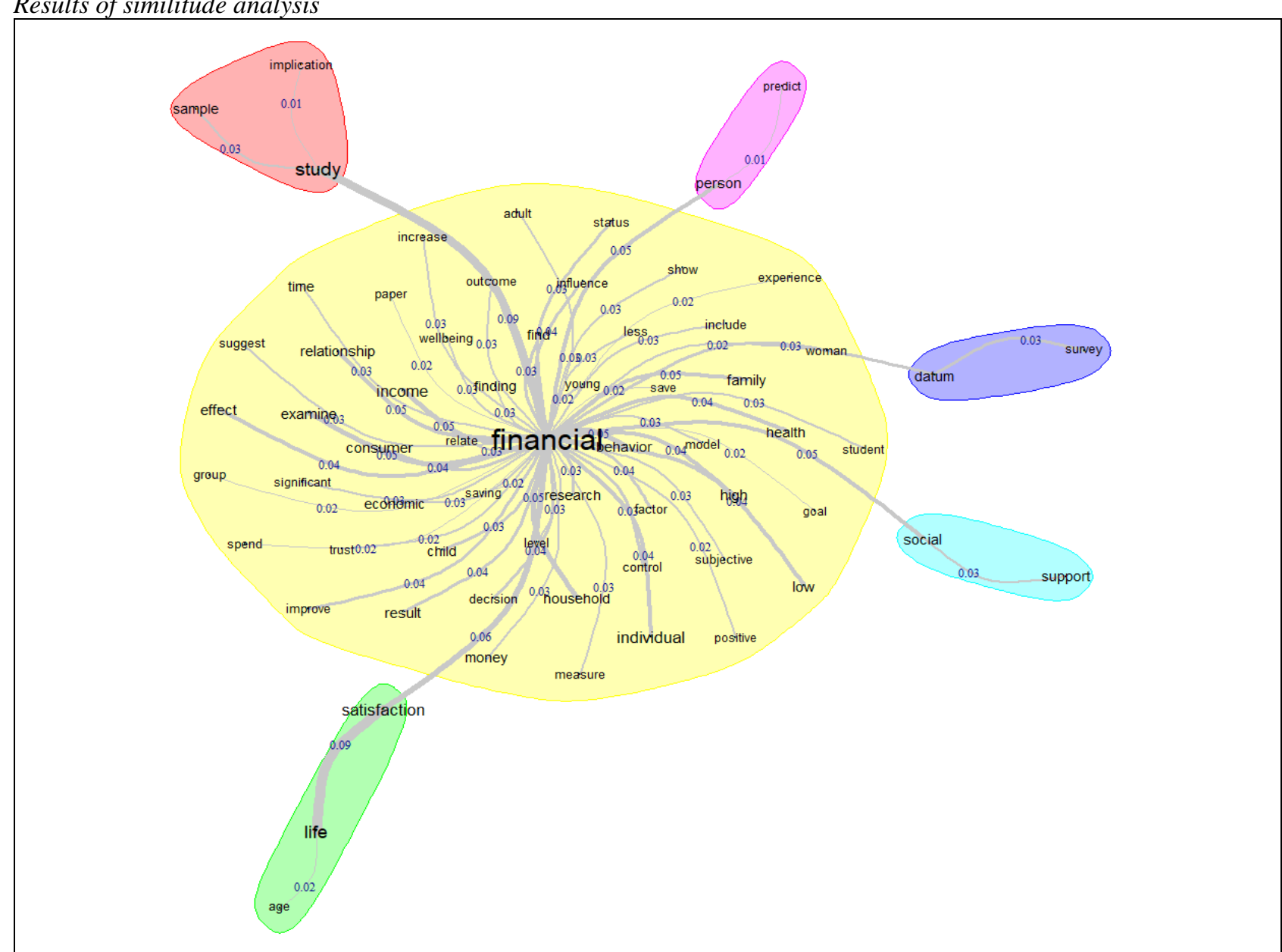

Source: Prepared by the authors according to RSL (2018) with Iramuteq.

From the results of the similarity graph in Figure 8, it is possible to verify the occurrence of a semantic range of words, in which the main one, which constitutes the nucleus, is "Financial". The connection intensity is expressed by the thickness of the line that connects it with the other words.

However, it turns out that we can find the two major ramifications in studies about life satisfaction. This result may show that researchers have expended more effort on research involving financial decision-making as a factor influencing the satisfaction of people's lives. We can also observe that the words connected with the nucleus are, in the main, coincident, for those found in greater prominence in the cloud of words.

\subsection{Content analysis}

To identify the main lines of research on financial well-being, we analyzed the content of the articles from the last two years of the research corpus (2017-2018). We opted for the last two years because they consider the most recent research regarding the studied theme. As a result of this time cut, 16 articles were obtained, presented in Table 3. 
Table 3

Summary and main conclusions of the most recent articles in the database

\begin{tabular}{|c|c|c|c|c|}
\hline Title & Year & Journal & Authors & Summary \\
\hline $\begin{array}{c}\text { Early retirement: } \\
\text { A meta-analysis } \\
\text { of its antecedent } \\
\text { and subsequent } \\
\text { correlates }\end{array}$ & 2018 & $\begin{array}{l}\text { Frontiers in } \\
\text { Psychology }\end{array}$ & $\begin{array}{c}\text { Topa G., } \\
\text { Depolo M., } \\
\text { Alcover C.M. }\end{array}$ & $\begin{array}{l}\text { Through a meta-analysis, the authors examined the } \\
\text { relationships between Early or voluntary retirement } \\
\text { and its antecedent and subsequent correlates. They } \\
\text { examined the potential moderator variables. } \\
\text { Moderators have explained only a reduced percentage } \\
\text { of variability of primary studies. Although the exam of } \\
\text { potential moderator factors, several unknown or not } \\
\text { measurable factors contribute to ER, there is very little } \\
\text { data available. }\end{array}$ \\
\hline $\begin{array}{l}\text { Effects of } \\
\text { financial } \\
\text { incentives on } \\
\text { saving outcomes } \\
\text { and material well- } \\
\text { being: evidence } \\
\text { from a } \\
\text { randomized } \\
\text { controlled trial in } \\
\text { Uganda }\end{array}$ & 2018 & $\begin{array}{c}\text { Journal of Policy } \\
\text { Analysis and } \\
\text { Management }\end{array}$ & $\begin{array}{l}\text { Wang J.S., } \\
\text { Ssewamala } \\
\text { F.M., } \\
\text { Neilands T.B., } \\
\text { Bermudez } \\
\text { L.G., } \\
\text { Garfinkel I., } \\
\text { Waldfogel J., } \\
\text { Brooks-Gunn } \\
\text { J., You J. }\end{array}$ & $\begin{array}{l}\text { The research sought to assess the effects of a combined } \\
\text { economy program and financial education workshops } \\
\text { and guidance on economic welfare outcomes and } \\
\text { materials for children affected by AIDS in rural } \\
\text { Uganda. Although micro-savings programs have } \\
\text { consistently increased access for formal financial } \\
\text { institutions, low utilization over time is also a } \\
\text { consistent problem in programs. Evidence indicates } \\
\text { that children who did not live with any of their } \\
\text { biological parents or lived in their current families for } \\
\text { fewer years were making fewer deposits. Older } \\
\text { children are less likely to open a savings account, } \\
\text { suggesting the importance of early intervention to } \\
\text { promote savings behaviors. On the other hand, having } \\
\text { lived in a family for more years was associated with } \\
\text { greater savings. Another important finding in this } \\
\text { study is that families have not reduced their } \\
\text { consumption of basic and necessary goods when } \\
\text { offered the opportunity to save. }\end{array}$ \\
\hline $\begin{array}{l}\text { Importance of } \\
\text { playing pickleball } \\
\text { for older adults' } \\
\text { subjective well- } \\
\text { being: A serious } \\
\text { leisure perspective }\end{array}$ & 2018 & $\begin{array}{l}\text { Journal of } \\
\text { Positive } \\
\text { Psychology }\end{array}$ & $\begin{array}{c}\text { Heo J., Ryu J., } \\
\text { Yang H., Kim } \\
\text { A.C.H., Rhee } \\
\text { Y. }\end{array}$ & $\begin{array}{l}\text { This study explored the relationship between financial } \\
\text { status, loneliness, leisure, and subjective well-being } \\
\text { (BES) among the elderly. From the regression } \\
\text { analyzes, the authors found that (a) serious leisure } \\
\text { significantly predicted BES, (b) financial situation was } \\
\text { not related to BES, and (c) loneliness was not related } \\
\text { to BES. They suggest that playing pickleball as a form } \\
\text { of serious leisure can add significant value to the daily } \\
\text { life of the elderly and contribute to successful aging. }\end{array}$ \\
\hline $\begin{array}{l}\text { Not materialistic, } \\
\text { just neurotic. The } \\
\text { mediating effect } \\
\text { of neuroticism on } \\
\text { the relationship } \\
\text { between attitudes } \\
\text { to material assets } \\
\text { and well-being }\end{array}$ & 2018 & $\begin{array}{c}\text { Personality and } \\
\text { Individual } \\
\text { Differences }\end{array}$ & $\begin{array}{c}\text { Górnik-Durose } \\
\text { M.E., Boroń } \\
\text { K. }\end{array}$ & $\begin{array}{l}\text { The research seeks to identify whether neuroticism } \\
\text { plays a significant role in the association between } \\
\text { materialism and attitudes towards money and well- } \\
\text { being. The result suggests that people's attitudes } \\
\text { towards material goods predict well-being mainly as } \\
\text { they accompany neuroticism. It has a limited direct } \\
\text { association with well-being after the statistical control } \\
\text { of the relationship between neuroticism and well- } \\
\text { being. The bivariate correlations between materialism, } \\
\text { neuroticism, and well-being are very similar to the } \\
\text { results of previous research. The results partially } \\
\text { supported the hypotheses related to attitudes towards } \\
\text { money. }\end{array}$ \\
\hline
\end{tabular}




\begin{tabular}{|c|c|c|c|c|}
\hline $\begin{array}{l}\text { The happy } \\
\text { culture: a } \\
\text { theoretical, meta- } \\
\text { analytic, and } \\
\text { empirical review } \\
\text { of the relationship } \\
\text { between culture } \\
\text { and wealth and } \\
\text { subjective well- } \\
\text { being }\end{array}$ & 2018 & $\begin{array}{c}\text { Personality and } \\
\text { Social } \\
\text { Psychology } \\
\text { Review }\end{array}$ & $\begin{array}{l}\text { Steel P., Taras } \\
\text { V., Uggerslev } \\
\text { K., Bosco F. }\end{array}$ & $\begin{array}{l}\text { The research analyzed the influence of cultural values } \\
\text { to increase financial and subjective well-being (SWB). } \\
\text { The results show some reversals at the individual level, } \\
\text { particularly the performance-oriented facet of } \\
\text { masculinity. Altogether, the happy nation has a low } \\
\text { power gap and a low avoidance of uncertainty. } \\
\text { However, it is high in femininity and individualism, } \\
\text { and these effects are interrelated but are still partially } \\
\text { independent of political and economic institutions. } \\
\text { Shortly, culture is important for individual and national } \\
\text { well-being. }\end{array}$ \\
\hline $\begin{array}{c}\text { Trust and } \\
\text { household debt }\end{array}$ & 2018 & $\begin{array}{l}\text { Review of } \\
\text { Finance }\end{array}$ & $\begin{array}{l}\text { Jiang D., Lim } \\
\text { S.S. }\end{array}$ & $\begin{array}{l}\text { Research shows that individuals with higher } \\
\text { confidence levels are less likely to default and have a } \\
\text { higher net worth. Values of trust drive the effect } \\
\text { inherited from cultural and family origins rather than } \\
\text { by beliefs of trust about others. The effect of trust is } \\
\text { evident among women, those with less education, } \\
\text { lower income, lower financial literacy, and higher } \\
\text { debt/income ratio. Evidence suggests that increasing } \\
\text { the confidence of individuals can improve the family's } \\
\text { financial well-being. }\end{array}$ \\
\hline $\begin{array}{l}\text { Young adults' life } \\
\text { outcomes and } \\
\text { well-being: } \\
\text { perceived } \\
\text { financial } \\
\text { socialization from } \\
\text { parents, the } \\
\text { romantic partner, } \\
\text { and young adults' } \\
\text { own financial } \\
\text { behaviors } \\
\end{array}$ & 2018 & $\begin{array}{c}\text { Journal of } \\
\text { Family and } \\
\text { Economic Issues }\end{array}$ & $\begin{array}{l}\text { Curran M.A., } \\
\text { Parrott E., Ahn } \\
\text { S.Y., Serido J., } \\
\quad \text { Shim S. }\end{array}$ & $\begin{array}{l}\text { A study shows that parents' financial socialization } \\
\text { begins to decline as their offspring enter young } \\
\text { adulthood and is supplanted by a perception that the } \\
\text { socialization forces exerted by personal experience and } \\
\text { the romantic partner are more important. }\end{array}$ \\
\hline $\begin{array}{l}\text { A person-centered } \\
\text { analysis of risk } \\
\text { factors that } \\
\text { compromise well- } \\
\text { being in emerging } \\
\text { adulthood }\end{array}$ & 2017 & $\begin{array}{c}\text { American } \\
\text { Journal of } \\
\text { Orthopsychiatry }\end{array}$ & $\begin{array}{l}\text { Newcomb- } \\
\text { Anjo S.E., } \\
\text { Barker E.T., } \\
\text { Howard A.L. }\end{array}$ & $\begin{array}{l}\text { The purpose of this study was to identify profiles of } \\
\text { risk in an emerging adulthood sample and to relate } \\
\text { these profiles to mental health and subjective and } \\
\text { academic well-being. The risk profiles were } \\
\text { subsequently related to mental health and subjective } \\
\text { and academic well-being outcomes, using a pseudo- } \\
\text { class draws approach. Analyses indicated that the risk- } \\
\text { pattern profiles differed in several ways across } \\
\text { outcomes. }\end{array}$ \\
\hline $\begin{array}{l}\text { Does self-control } \\
\text { predict financial } \\
\text { behavior and } \\
\text { financial well- } \\
\text { being? }\end{array}$ & 2017 & $\begin{array}{c}\text { Journal of } \\
\text { Behavioral and } \\
\text { Experimental } \\
\text { Finance }\end{array}$ & $\begin{array}{l}\text { Strömbäck C., } \\
\text { Lind T., } \\
\text { Skagerlund K., } \\
\text { Västfjäll D., } \\
\text { Tinghög G. }\end{array}$ & $\begin{array}{l}\text { The authors explore individual differences in self- } \\
\text { control and other non-cognitive factors on financial } \\
\text { behavior and financial well-being. The authors sent a } \\
\text { survey containing measures of financial behavior, } \\
\text { subjective financial well-being, self-control, optimism, } \\
\text { deliberative thinking, and demographic variables to a } \\
\text { representative sample of the Swedish population. The } \\
\text { main findings extend the behavioral life-cycle } \\
\text { hypothesis beyond savings behavior to include general } \\
\text { financial behavior. People with good self-control are } \\
\text { more likely to save money from every paycheck, have } \\
\text { better financial behavior, feel less anxious about } \\
\text { financial matters, and feel more secure in their current } \\
\text { and future financial situation. }\end{array}$ \\
\hline
\end{tabular}




\begin{tabular}{|c|c|c|c|c|}
\hline $\begin{array}{l}\text { Financial well- } \\
\text { being: a } \\
\text { conceptualization } \\
\text { and research } \\
\text { agenda }\end{array}$ & 2017 & $\begin{array}{l}\text { Journal of } \\
\text { Business } \\
\text { Research }\end{array}$ & $\begin{array}{l}\text { Brüggen E.C., } \\
\text { Hogreve J., } \\
\text { Holmlund M., } \\
\text { Kabadayi S., } \\
\text { Löfgren M. }\end{array}$ & $\begin{array}{l}\text { The research seeks to expand knowledge about } \\
\text { financial well-being and brings three contributions to } \\
\text { the discussion. First, it proposes a new definition based } \\
\text { on a perception of financial well-being and links it to } \\
\text { an individual's current and expected standard of living } \\
\text { and financial freedom. Develops a structure that } \\
\text { distinguishes the key elements of financial well-being, } \\
\text { namely, financial interventions and behaviors, } \\
\text { consequences, contextual factors, and personal factors. }\end{array}$ \\
\hline $\begin{array}{l}\text { Money and the } \\
\text { quality of life }\end{array}$ & 2017 & $\begin{array}{c}\text { Journal of } \\
\text { Central Banking } \\
\text { Theory and } \\
\text { Practice }\end{array}$ & $\begin{array}{c}\text { Luburić R., } \\
\text { Fabris N. }\end{array}$ & $\begin{array}{l}\text { The article analyzes the direct and indirect } \\
\text { relationships between effective and efficient } \\
\text { management of money and the financial and material } \\
\text { factors of life, employment, health, education, leisure } \\
\text { and social activities, economic and physical security, } \\
\text { human rights and freedoms, protection of the } \\
\text { environment, and general satisfaction with life, } \\
\text { decisive to life quality formation. }\end{array}$ \\
\hline $\begin{array}{l}\text { It's all about the } \\
\text { money (for some): } \\
\text { consequences of } \\
\text { financially } \\
\text { contingent self- } \\
\quad \text { worth }\end{array}$ & 2017 & $\begin{array}{c}\text { Personality and } \\
\text { Social } \\
\text { Psychology } \\
\text { Bulletin }\end{array}$ & $\begin{array}{l}\text { Park L.E., } \\
\text { Ward D.E., } \\
\text { Naragon- } \\
\text { Gainey K. }\end{array}$ & $\begin{array}{l}\text { The research aimed to identify how financial success } \\
\text { can be linked to self-esteem contingencies for some } \\
\text { individuals (but not for others), with implications for } \\
\text { well-being and responses to financial threats. Results } \\
\text { indicate that participants with greater contingencies of } \\
\text { financial self-esteem were less likely to make } \\
\text { extravagant spending decisions after a financial threat. }\end{array}$ \\
\hline $\begin{array}{l}\text { I feel happy that I } \\
\text { can be useful to } \\
\text { others: } \\
\text { preliminary study } \\
\text { of East African } \\
\text { women and their } \\
\text { remittance } \\
\text { behavior }\end{array}$ & 2017 & $\begin{array}{c}\text { Journal of } \\
\text { Family and } \\
\text { Economic Issues }\end{array}$ & $\begin{array}{l}\text { Muruthi B., } \\
\text { Watkins K., } \\
\text { McCoy M., } \\
\text { Muruthi J.R., } \\
\text { Kiprono F.J. }\end{array}$ & $\begin{array}{l}\text { The study investigated the experiences of remittances } \\
\text { of seven women immigrants from East Africa, } \\
\text { Rwanda, and Kenya. The survey revealed five themes: } \\
\text { (1) Women felt that their families had made financial } \\
\text { sacrifices for them, (2) Women assumed the family's } \\
\text { financial responsibilities, (3) Women felt that their } \\
\text { families in their home country had distorted financial } \\
\text { expectations of them, (4) Women felt guilty about their } \\
\text { limited finances and inability to send more money to } \\
\text { their families, and lastly (5) women invested or had } \\
\text { plans to invest in their home country. The results show } \\
\text { that the collectivist values and financial responsibility } \\
\text { for the family are the reasons for the remittance. }\end{array}$ \\
\hline $\begin{array}{l}\text { Individual pension } \\
\text { plans in Spain: } \\
\text { How expected } \\
\text { change in future } \\
\text { income and } \\
\text { liquidity } \\
\text { constraints shape } \\
\text { the behavior of } \\
\text { households } \\
\end{array}$ & 2017 & $\begin{array}{c}\text { Journal of } \\
\text { Family and } \\
\text { Economic Issues }\end{array}$ & $\begin{array}{l}\text { Moreno- } \\
\text { Herrero D., } \\
\text { Salas-Velasco } \\
\text { M., Sánchez- } \\
\text { Campillo J. }\end{array}$ & $\begin{array}{l}\text { The survey revealed that expectations of lower future } \\
\text { earnings, along with preferences for financial and } \\
\text { educational risk, have an important influence on the } \\
\text { likelihood of enrolling in a private pension plan. } \\
\text { University education minimizes the myopic behavior } \\
\text { of families, making them more forward-looking and } \\
\text { cautious about their future well-being. Also, the results } \\
\text { revealed that liquidity constraints negatively affect the } \\
\text { total amount of money saved for retirement. }\end{array}$ \\
\hline $\begin{array}{l}\text { Psychological } \\
\text { biases of } \\
\text { individual } \\
\text { investors and } \\
\text { financial } \\
\text { satisfaction }\end{array}$ & 2017 & $\begin{array}{l}\text { Journal of } \\
\text { Consumer } \\
\text { Behaviour }\end{array}$ & Sahi SK. & $\begin{array}{l}\text { The research aimed to explore the bias of the investor } \\
\text { and check if they are related to the financial } \\
\text { satisfaction of individuals. Financial satisfaction is the } \\
\text { measure of satisfaction with a person's financial } \\
\text { situation. The results showed that the bias of } \\
\text { overconfidence, the bias of trust in the specialist, and } \\
\text { the bias of self-control have a positive and significant } \\
\text { association with the levels of financial satisfaction. } \\
\text { The author observed the association of some other } \\
\text { biases with financial satisfaction under certain } \\
\text { conditions of control. }\end{array}$ \\
\hline
\end{tabular}




\begin{tabular}{|c|c|c|c|c|}
\hline $\begin{array}{c}\text { Working up a } \\
\text { debt: students as } \\
\text { vulnerable } \\
\text { consumers }\end{array}$ & 2017 & $\begin{array}{c}\text { Journal of } \\
\text { Marketing for } \\
\text { Higher } \\
\text { Education }\end{array}$ & $\begin{array}{c}\text { The survey examines student debt in order to initiate a } \\
\text { Fobson J., } \\
\text { Hindle C. } \\
\text { broader debate about student vulnerability. The main } \\
\text { conclusions are: the reasons for indebtedness are many } \\
\text { and varied, generally linked to changes associated with } \\
\text { the year of study. The results suggest the student's lack } \\
\text { of concern about debts with potential long-term } \\
\text { consequences. }\end{array}$ \\
\hline
\end{tabular}

Source: organized by the authors.

The systematic review demonstrated that despite the many recent advances, with the expansion of studies on financial well-being, the research agenda proposed by Brüggen et al. (2017) is still adequate and challenging. We agree with the six dimensions proposed by the authors: i) concept of financial well-being; ii) measure financial well-being; iii) interventions to improve the financial well-being and financial behavior, iv) consequences of financial well-being, v) contextual factors of financial well-being; vi) personal factors that affect financial well-being. In particular, we recognize the urgency in consolidating the first two items that are fundamental to the progress of the others.

Most of the measures currently used in empirical studies have not undergone psychometric validations since the articles that presented them did not have this objective. Therefore, we understand that the absence of psychometric validation procedures for most existing scales corroborates the need to adopt more robust procedures for constructing the financial well-being scales.

Another important point is the validation of the existing scales for other countries. Many articles use scales already proposed by previous studies without concern for cross-cultural adaptation, resulting in important measurement flaws. We also observed that the studies focus on scales that propose to assess Financial Well-Being at the individual level, still needing an overall development of scales capable of assessing financial well-being at a family level, social groups, or even from a society/country. Thus, we understand that from the construction and validation of a set of measures of financial well-being, for different levels of measurement (individual, family, society), a broad and rapid advance in studies involving antecedents and consequences of Well-Being will be possible. It includes the use of broader methodologies and bases and new technologies for measurement.

\section{CONCLUDING REMARKS}

This research aimed to develop a Systematic Review of Literature on the theme of financial well-being. As a pretension of contributing to the scientific knowledge of the area of financial wellbeing, we systematized a research protocol according to the methodological rigor demanded in the SRL, which resulted in the composition of the research corpus.

Our results show that the research corpus was composed of 78 articles and 215 authors and co-authors, distributed in 24 countries, with a higher concentration in the United States $(61.5 \%)$. The article distribution period includes the years 1987 to 2018, emphasizing 2016, with 12 articles published.

The networks of cooperation between institutions, Florida State University, the University of São Paulo, and the Department of Sociology are the institutions that have stood out most in conducting cooperative research. Also, we can see that Florida State University and the University of São Paulo are the institutions that present the most recent articles on the subject. As for the cooperation networks between the authors, the authors Diener has a total of 87 citations and 28 relational links; Lusardi with 34 citations and 15 relational nodes; and Kasser, with 29 citations and 19 relational nodes. These are the authors who most developed cooperative work on the financial well-being of people in the period under review.

In the bibliographic coupling of the quotations analysis, we highlight the work of Oishi, Diener, Lucas, and Suh ("Cross-cultural variations in predictors of life satisfaction: Perspectives from 
needs and values"). It presented 270 citations, representing $44.40 \%$ of the citations received by all the documents in Cluster 1 and $20.05 \%$ concerning all clusters.

The words "Finance", "Study", "Live", "Satisfaction", and "Income" presented the highest frequency of occurrence. Therefore, the results of this analysis seem to indicate that the researches of greater representativeness in the academic environment have directed their focus to themes aimed at identifying the financial satisfaction in the life of the people through the analysis of the family income. In the analysis of similarity, one can perceive the occurrence of a semantic range of words where the main one, which constitutes the nucleus, was the "Financial".

Moreover, the systematic review demonstrated that despite the many recent advances, with the expansion of studies on financial well-being, the research agenda proposed by Brüggen et al. (2017) is still adequate and challenging.

This article's originality is that it is the first systematic review of the literature on financial well-being. Thus, the systematization of knowledge can serve as a scientific basis to develop other research. The work presents an exhaustive, systematic review of the literature in its field. However, it is still important to emphasize that this study has limitations the periodic inclusion belonging to the first and second quartile of citation in the Scimago. We cannot disregard that we can find relevant publications published in other journals, not classified or presented in other formats, such as books and articles in conferences. For this reason, we suggest incorporating studies from other journal bases and testing new protocols in different contextual areas that can be studied individually.

For future research, we suggest surveying the main demographic and socioeconomic factors that most influence BEF. When carrying out other research of this nature, it is possible to examine which cognitive skills associated with the learning process influence the behavior of economic agents and their well-being. This knowledge is fundamental to improve financial decisions that positively impact the well-being, which is consistent with the proposal of Strömbäck, Lind, Skagerlund, Västfjäll, and Tinghög (2017).

Another suggestion for future research would be to investigate the influence of personality traits of economic agents (e.g., openness towards experiences, conscientiousness, affability, stability/neuroticism, and extroversion) on the good practices of financial decisions, which impact economic and financial well-being. A promising path is to assess how financial well-being can influence different aspects of consumers' purchasing decisions. An example is a study by Hampson, Ma, and Wang (2018) that analyzes how the loss of financial well-being causes individuals to buy less imported products and more domestic products.

Finally, we suggest including indicators such as positive or negative effects or the inclusion of constructs such as aging, health status, personal growth, happiness, social connections, civic engagement, work-life balance, and personal security. According to what Heo, Ryu, Yang, Kim, and Rhee (2017) tangentially announced, one can relationally explore characteristics such as perseverance, significant effort, career development, and identity.

\section{REFERENCES}

Adam, A. M., Frimpong, S., \& Boadu, M. O. (2017). Financial literacy and financial planning: Implication for financial well-being of retirees. Business and Economic Horizons, 13(2), 224-236. https://doi.org/10.15208/beh.2017.17

Aggarwal, S. (2014). Developing an index for measuring financial well-being in a geography. Retrieved December 10, 2018, from https://www.dvara.com/blog/2011/02/14/developing-an-index-formeasuring-financial-well-being-in-a-geography/.

Araújo, P. C., \& Guimarães, J. A. C. (2017). Análise de Citação da produção científica do domínio de epistemologia da organização do conhecimento. In XVIII Encontro Nacional de Pesquisa em Ciência da Informação.

Arber, S., Fenn, K., \& Meadows, R. (2014). Subjective financial well-being, income and health inequalities in mid and later life in Britain. Social Science and Medicine, 100, 12-20. 
https://doi.org/10.1016/j.socscimed.2013.10.016

Biolchini, J. C. de A., Mian, P. G., Natali, A. C. C., Conte, T. U., \& Travassos, G. H. (2007). Scientific research ontology to support systematic review in software engineering. Advanced Engineering Informatics, 21(2), 133-151. https://doi.org/10.1016/j.aei.2006.11.006

Boyce, C. J., Wood, A. M., \& Ferguson, E. (2016). Individual differences in loss aversion:

Conscientiousness predicts how life satisfaction responds to losses versus gains in income. Personality and Social Psychology Bulletin, 42(4), 471-484. https://doi.org/10.1177/0146167216634060

Brizola, J., \& Fantin, N. (2016). Revisão da literatura e revisão sistemática da Literatura. Relva - Revista de Educação Do Vale Do Arianos, 3(2), 2339.

Brüggen, E. C., Hogreve, J., Holmlund, M., Kabadayi, S., \& Löfgren, M. (2017). Financial well-being: A conceptualization and research agenda. Journal of Business Research, 79, 228-237. https://doi.org/10.1016/j.jbusres.2017.03.013

Campanario, J. M. (2015). Providing impact: The distribution of JCR journals according to references they contribute to the 2-year and 5-year journal impact factors. Journal of Informetrics, 9(2), 398-407. https://doi.org/10.1016/j.joi.2015.01.005

Carvalho, M. M. de. (1975). Análises bibliométricas da literatura de química no Brasil. Ciência da Informação, 4(2), 119-141.

Chan, K. Y. K., Chau, A. W. L., Chan, S. F. (2012). Financial knowledge and aptitudes: Impacts on college students' financial well-being. College Student Journal, 46(1), 114-133.

Chan, S. W., Omar, S. S., \& Yong, W. L. (2018). Financial well-being among Malaysian manufacturing employees. Management Science Letters, 8(6), 691-698. https://doi.org/10.5267/j.msl.2018.4.020

Chancellor, J., \& Lyubomirsky, S. (2011). Happiness and thrift: When (spending) less is (hedonically) more. Journal of Consumer Psychology, 21(2), 131-138

Collins, J. M., \& Urban, C. (2020). Measuring financial well-being over the life course. European Journal of Finance, 26(4-5), 341-359.

Consumer Financial Protection Bureau. (2015). Financial well being: The goal of financial education. Financial well-being: The goal of financial education. Retrieved from http://files.consumerfinance.gov/f/201501_cfpb_report_financial-well-being.pdf

Creed, P. A., \& Bartrum, D. A. (2008). Personal control as a mediator and moderator between life strains and psychological well-being in the unemployed. Journal of Applied Social Psychology, 38(2), 460-481. https://doi.org/10.1111/j.1559-1816.2007.00313.x

Creed, P. A., \& Watson, T. (2003). Age, Gender, psychological wellbeing and the impact of losing the latent and manifest benefits of employment in unemployed people. Australian Journal of Psychology, 55(2), 95-103. https://doi.org/10.1080/00049530412331312954

Cronin, P., Ryan, F., \& Coughlan, M. (2004). Undertaking a Literature Review: a step-by-step approach, British Journal of Nursing, 4(4), 411-429. https://doi.org/10.1177/107808747000500401

Delafrooz, N., \& Paim, L. H. (2011). Determinants of financial wellness among Malaysia workers. African Journal of Business Management, 5(24), 10092-10100. https://doi.org/10.5897/ajbm10.1267

DePaolo, C. A., \& Wilkinson, K. (2014). Get your head into the clouds: Using word clouds for analyzing qualitative assessment data. TechTrends, 58(3), 38-44. https://doi.org/10.1007/s11528-014-0750-9

Diniz, A. P. C., Vieira, K. M., Potrich, A. C. G., \& Campara, J. P. (2014). Influência das variáveis socioeconômicas e demográficas no bem-estar financeiro: Um estudo do comportamento Maranhense. Revista UNIABEU, 7(17), 218-234.

Diniz, A. P. C., Vieira, K. M., Potrich, A. C. G., \& Campara, J. P. (2015). Bem-Estar financeiro: Uma análise multifatorial do comportamento Maranhense. Estudos do CEPE, (42), 186. https://doi.org/10.17058/cepe.v0i42.6317

Disney, R., \& Gathergood, J. (2011). Financial literacy and indebtedness: New evidence for uk consumers. Discussion Papers 11/05, University of Nottingham, Centre for Finance, Credit and Macroeconomics (CFCM).

Dowling, N. A., Corney, T., \& Hoiles, L. (2009). Financial management practices and money attitudes as determinants of financial problems and dissatisfaction in young male Australian workers. Journal of Financial Counseling and Planning, 20(2), 5-13.

Dynan, Karen E. 2009. Changing Household Financial Opportunities and Economic Security. Journal of Economic Perspectives, 23(4), 49-68.

Easterlin, R. A. (2006). Life cycle happiness and its sources. Intersections of psychology, economics, and 
demography. Journal of Economic Psychology, 27(4), 463-482.

https://doi.org/10.1016/j.joep.2006.05.002

Egghe, L., \& Rousseau, R. (2002). Co-citation, bibliographic coupling and a characterization of lattice citation networks. Scientometrics, 55(3), 349-361. https://doi.org/10.1023/A:1020458612014

Falagas, M. E., Pitsouni, E. I., Malietzis, G. A., \& Pappas, G. (2008). Comparison of PubMed, Scopus, Web of Science, and Google Scholar: Strengths and weaknesses. FASEB Journal, 22(2), 338-342. https://doi.org/10.1096/fj.07-9492LSF

Falahati, L., Sabri, M. F., \& Paim, L. H. J. (2012). Assessment a model of financial satisfaction predictors: Examining the mediate effect of financial behaviour and financial strain. World Applied Sciences Journal, 20(2), 190-197. https://doi.org/10.5829/idosi.wasj.2012.20.02.1832

Fazli Sabri, M., Cook, C. C., \& Gudmunson, C. G. (2012). Financial well-being of Malaysian college students. Asian Education and Development Studies, 1(2), 153-170. https://doi.org/10.1108/20463161211240124

Franko, W. W. (2020). How state responses to economic crisis shape income inequality and financial wellbeing. State Politics \& Policy Quarterly. doi:10.1177/1532440020919806

Fraga, L. S., Vieira, K. M., \& Paraboni, A. L. (2016). Bem-estar financeiro: uma análise sob a perspectiva da renda. Revista de Finanças Aplicadas, 7(4), 1-28.

Ghazali, M. S., Alwi, S. F. S., Abd Aziz, N. N., \& Hazudin, S. F. (2020). Pathway to financial well-being: A review on the role of psychological factors. Environment-Behaviour Proceedings Journal, 5(13), 5561.

Greninger, S. (1996). Ratios and benchmarks for measuring the financial well-being of families and individuals. Financial Services Review, 5(1), 57-70. https://doi.org/10.1016/s1057-0810(96)90027-x

Guo, L., Arnould, E. J., Gruen, T. W., \& Tang, C. (2013). Socializing to co-produce: Pathways to consumers' financial well-being. Journal of Service Research, 16(4), 549-563. https://doi.org/10.1177/1094670513483904

Gutter, M., \& Copur, Z. (2011). Financial behaviors and financial well-being of college students: Evidence from a national survey. Journal of Family and Economic Issues, 32(4), 699-714. https://doi.org/10.1007/s10834-011-9255-2

Hampson, D. P., Ma, S., \& Wang, Y. G. (2018). Perceived financial well-being and its effect on domestic product purchases: An empirical investigation in Brazil. International Marketing Review, 35(6), 914935.

Heo, J., Ryu, J., Yang, H., Chan, A.C.H., \& Rhee, Y. (2017). Importance of playing pickleball for older adults' subjective well-being: A serious leisure perspective. The Journal of Positive Psychology. 13(1), 67-77. http://dx.doi.org/10.1080/17439760.2017.1374438

Hira, T., \& Mugenda, O. (1999). The relationships between self-worth and financial beliefs, behavior, and satisfaction. Journal of Family and Consumer Sciences, 91(4), 76-81.

Huston, S. J. (2010). Measuring financial literacy. The Journal of Consumer Affairs, 44(2), 296-316. https://doi.org/10.1111/j.1745-6606.2010.01170.x

Joo, S. H., \& Grable, J. E. (2004). An exploratory framework of the determinants of financial satisfaction. Journal of Family and Economic Issues, 25(1), 25-50. https://doi.org/10.1023/B:JEEI.0000016722.37994.9f

Kahneman, D., \& Deaton, A. (2010). High income improves evaluation of life but not emotional well-being. Proceedings of the National Academy of Sciences of the United States of America, 107(38), 1648916493. https://doi.org/10.1073/pnas.1011492107

Kasser, T., \& Ryan, R. (1993). A dark side of the American dream: Correlates of financial success as a central life. Journal of Personality and Social Psychology, 65(2), 410-422.

Kessler, M. M. (1965). Comparison of the results of bibliographic coupling and analytic subject indexing. American Documentation, 16(3), 223-233. https://doi.org/10.1002/asi.5090160309

Kitchenham, B. (2004). Procedures for performing systematic reviews. Joint technical report software (Vol. 37). https://doi.org/10.5144/0256-4947.2017.79

Kunkel, F. I. R., Vieira, K. M., \& Potrich, A. C. G. (2015). Causas e consequências da dívida no cartão de crédito: uma análise multifatores. Revista de Administração, 50(2), 169-182. https://doi.org/10.5700/rausp1192

Leach, L. J., Hayhoe, C. R., \& Turner, P. R. (1999). Factors affecting perceived economic well-being of college students: A gender perspective. Journal of Financial Counseling and Planning, 10(2), 11-24. 
Lekes, N., Gingras, I., Philippe, F. L., Koestner, R., \& Fang, J. (2010). Parental autonomy-support, intrinsic life goals, and well-being among adolescents in China and North America. Journal of Youth and Adolescence, 39(8), 858-869. https://doi.org/10.1007/s10964-009-9451-7

Li, M., Porter, A. L., \& Wang, Z. L. (2017). Evolutionary trend analysis of nanogenerator research based on a novel perspective of phased bibliographic coupling. Nano Energy, 34, 93-102. https://doi.org/10.1016/j.nanoen.2017.02.020

Lown, J. M., \& Ju, I. S. (1992). A model of credit use and financial satisfaction. Financial Counseling and Planning, 3(January 1992), 5.

Lucas, E. O., \& Garcia-Zorita, J. C. (2014). Produção científica sobre capital social: estudo por acoplamento bibliográfico. Em Questão, 20(3), 27-42. https://doi.org/10.1057/9781137020758

Lusardi, A., \& Mitchell, O. S. (2007). Baby boomer retirement security: The roles of planning, financial literacy, and housing wealth. Journal of Monetary Economics, 54(1), 205-224. https://doi.org/10.1016/j.jmoneco.2006.12.001

Lusardi, A., \& Mitchell, O. S. (2014). The economic importance of financial literacy: Theory and evidence. Journal of Economic Literature, 52, 5-44.

Lyons, A. C., \& Yilmazer, T. (2005). Health and financial strain: Evidence from the survey of consumer finances. Southern Economic Journal, 71(4), 873. https://doi.org/10.2307/20062085

Mahendru, M. (2020). Financial well-being for a sustainable society: A road less travelled. Qualitative Research in Organizations and Management. Vol. ahead-of-print No. ahead-of-print. https://doi.org/10.1108/QROM-03-2020-1910

Malone, K., Stewart, S. D., Wilson, J., \& Korsching, P. F. (2010). Perceptions of financial well-being among American women in diverse families. Journal of Family and Economic Issues, 31(1), 63-81. https://doi.org/10.1007/s10834-009-9176-5

McCabe, S., Joldersma, T., \& Li, C. (2010). Understanding the benefi ts of social tourism : Linking participation to. International Journal of Tourism Research, 12(June), 761-773. https://doi.org/10.1002/jtr

Mookherjee, H. N. (1997). Marital status, gender, and perception of weil-being. Journal of Social Psychology, 137(1), 95-105. https://doi.org/10.1080/00224549709595417

Netemeyer, R. G., Warmath, D., Fernandes, D., \& Lynch Jr, J. G. (2018). How am I doing? Perceived financial well-being, its potential antecedents, and its relation to overall well-being. Journal of Consumer Research, 45(1), 68-89.

Norvilitis, J. M., Szablicki, P. B., \& Wilson, S. D. (2003). Factors influencing levels of credit-card debt in college students. Journal of Applied Social Psychology, 33(5), 935-947. https://doi.org/10.1111/j.1559-1816.2003.tb01932.x

O’Neill, B., Sorhaindo, B., Xiao, J. J., \& Garman, E. T. (2005). Financially distressed consumers: Their financial practices, financial well-being, and health. Journal of Financial Counseling and Planning, 16(1), $73-87$.

Oishi, S., Diener, E., Lucas, R., \& Suh, E. (2009). Cross-cultural variations in predictors of life satisfaction: Perspectives from needs and values. https://doi.org/10.1007/978-90-481-2352-0

Penn, D. (2009). Financial well-being in an urban area: An application of multiple imputation. Applied Economics, 41(23), 2955-2964. https://doi.org/10.1080/00036840701367507

Plagnol, A. C. (2011). Financial satisfaction over the life course: The influence of assets and liabilities. Journal of Economic Psychology, 32(1), 45-64. https://doi.org/10.1016/j.joep.2010.10.006

Ponchio, M. C., Cordeiro, R. A., \& Goncalves, V. N. (2019). Personal factors as antecedents of perceived financial well-being: evidence from Brazil. International Journal of Bank Marketing, 37(4), 10041024.

Prawitz, A. D., Garman, E. T., Sorhaindo, B., O’Neill, B., Kim, J., \& Drentea, P. (2006). InCharge financial distress/financial well-being scale: Development, administration, and score interpretation. Journal of Financial Counseling and Planning, 17(1), 34-50.

Provdanov, C. C., \& Freitas, E. C. De. (2013). Metodologia do trabalho científico: métodos e técnicas da pesquisa e do trabalho acadêmico. Novo Hamburgo: Feevale. https://doi.org/10.1017/CBO9781107415324.004

Rahtz, D.R., Sirgy, M. J., \& Meadow, H. L. (1989). The elderly audience: Correlates of television orientation. Journal of Advertising, 18(3), 9-20.

Rick, S.I., Small, D.A., \& Finkel, E. J,. (2011) Fatal (Fiscal) Attraction: Spendthrifts and Tightwads in 
Marriage. Journal of Marketing Research, 48(2), 228 -237. https://doi.org/10.1509/jmkr.48.2.228

Santos, D. B., Mendes-Da-Silva, W., Flores, E., \& Norvilitis, J. M. (2016). Predictors of credit card use and perceived financial well-being in female college students: A Brazil-United States comparative study. International Journal of Consumer Studies, 40(2), 133-142. https://doi.org/10.1111/ijcs.12234

Sarofim, S., Minton, E., Hunting, A., Bartholomew, D. E., Zehra, S., Montford, W., Cabano, F., \& Paul, P. (2020) Religion's influence on the financial well-being of consumers: A conceptual framework and research agenda. Journal of Consumer Affairs, 54, 1028-1061

Scimago Journal \& Country Rank (SJR). 2018. https://www.scimagojr.com/

Shambare, R., \& Rugimbana, R. (2007). Financial literacy among the educated: An exploratory study of selected university students in South Africa. Thunderbird International Business Review, 49(5), 630631. https://doi.org/10.1002/tie

Shim, S., Xiao, J. J., Barber, B. L., \& Lyons, A. C. (2009). Pathways to life success: A conceptual model of financial well-being for young adults. Journal of Applied Developmental Psychology, 30(6), 708-723. https://doi.org/10.1016/j.appdev.2009.02.003

Small, H. (1973). Co-citation in the scientific literature: A new measure of the relationship between two documents. Journal of the American Society for Information Science, 24(4), 265-269. Retrieved from http://onlinelibrary.wiley.com/doi/10.1002/asi.4630240406/abstract\%5CnD:\%5CZotero_Data\%5CZot ero\%5CProfiles\%5C1sqw9v0j.default\%5Czotero\%5Cstorage\%5CGCR7NPQA\%5Cabstract.html

Sorgente, A., \& Lanz, M. (2017). Emerging adults' financial well-being: A scoping review. Adolescent Research Review, 2(4), 255-292.

Stanca, L. (2012). Suffer the little children: Measuring the effects of parenthood on well-being worldwide. Journal of Economic Behavior and Organization, 81(3), 742-750. https://doi.org/10.1016/j.jebo.2010.12.019

Strömbäck, C., Lind, T., Skagerlund, K., Västfjäll, D., Tinghög, G. (2017). Does self-control predict financial behavior and financial well-being?, Journal of Behavioral and Experimental Finance, 14, 30-38. https://doi.org/10.1016/j.jbef.2017.04.002.

Sumarwan, U. (1990). A managerial system approach to factors influencing satisfaction with households' financial status, Master's thesis, Iowa State University. 1-116.

Taft, M. K., Hosein, Z. Z., \& Mehrizi, S. M. T. (2013). The relation between financial literacy, financial wellbeing and financial concerns. International Journal of Business and Management, 8(11), 63-75. https://doi.org/10.5539/ijbm.v8n11p63

Tranfield, D., Denyer, D., \& Smart, P. (2003). Towards a methodology for developing evidence-informed management knowledge by means of systematic review. British Journal of Management, 14, 207-222. https://doi.org/10.1111/1467-8551.00375

Vieira, K. M., \& Kreutz, R. R. (2018). Endividado ou poupador: impacto das variáveis sociodemográficas e do gerenciamento financeiro. Revista Pretexto, 19(3), 81-98. https://doi.org/10.21714/pretexto.v19i3.5374

Vlaev, I., \& Elliott, A. (2014). Financial well-being components. Social Indicators Research, 118(3), 11031123. https://doi.org/10.1007/s11205-013-0462-0

Wallin, J. A. (2005). Bibliometric methods: Pitfalls and possibilities. Basic and Clinical Pharmacology and Toxicology, 97(5), 261-275. https://doi.org/10.1111/j.1742-7843.2005.pto_139.x

Zhao, D., \& Strotmann, A. (2008). Evolution of research activities and intellectual influences in information science 1996-2005: Introducing author bibliographic-coupling analysis. Journal of the American Society for Information Science and Technology, 59(13), 2070-2086. https://doi.org/10.1002/asi

Zupic, I., \& Čater, T. (2015). Bibliometric methods in management and organization. Organizational Research Methods, 18(3), 429-472. https://doi.org/10.1177/1094428114562629 